\title{
Dendritic Cell-Mediated Th2 Immunity and Immune Disorders
}

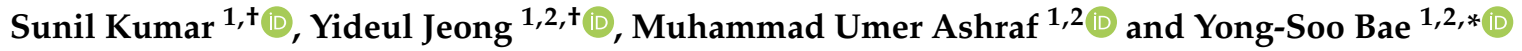 \\ 1 Science Research Center (SRC) for Immune Research on Non-Lymphoid Organ (CIRNO), \\ Sungkyunkwan University, Jangan-gu, Suwon, Gyeonggi-do 16419, Korea; sunilkumar@skku.edu (S.K.); \\ skyiller@gmail.com (Y.J.); drumerashraf@gmail.com (M.U.A.) \\ 2 Department of Biological Science, Sungkyunkwan University, Jangan-gu, Suwon, Gyeonggi-do 16419, Korea \\ * Correspondence: ysbae04@skku.edu; Tel.: +82-31-299-4149; Fax: +82-31-290-7087 \\ + These authors contributed equally to this work.
}

Received: 30 March 2019; Accepted: 29 April 2019; Published: 1 May 2019

check for updates

\begin{abstract}
Dendritic cells (DCs) are the professional antigen-presenting cells that recognize and present antigens to naïve $\mathrm{T}$ cells to induce antigen-specific adaptive immunity. Among the T-cell subsets, T helper type 2 (Th2) cells produce the humoral immune responses required for protection against helminthic disease by activating B cells. DCs induce a Th2 immune response at a certain immune environment. Basophil, eosinophil, mast cells, and type 2 innate lymphoid cells also induce Th2 immunity. However, in the case of DCs, controversy remains regarding which subsets of DCs induce Th2 immunity, which genes in DCs are directly or indirectly involved in inducing Th2 immunity, and the detailed mechanisms underlying induction, regulation, or maintenance of the DC-mediated Th2 immunity against allergic environments and parasite infection. A recent study has shown that a genetic defect in DCs causes an enhanced Th2 immunity leading to severe atopic dermatitis. We summarize the Th2 immune-inducing DC subsets, the genetic and environmental factors involved in DC-mediated Th2 immunity, and current therapeutic approaches for Th2-mediated immune disorders. This review is to provide an improved understanding of DC-mediated Th2 immunity and Th1/Th2 immune balancing, leading to control over their adverse consequences.
\end{abstract}

Keywords: dendritic cells; Th2 immunity; genetic factors; environmental factors; Th2 disorders; therapeutic approaches

\section{Introduction}

Dendritic cells (DCs) are the professional antigen-presenting cells (APCs) that play an important role in immune defense by activating the adaptive immune system. DCs were first discovered by Steinman and Cohn in 1973 [1], and extensive studies have since been conducted related to the various DC subsets in humans and mice and their characteristics [2]. Different DC subsets or the same DC subset in different environments can induce different T-cell immunity [3-5]. T helper type 2 (Th2) immunity mainly performs two important interconnected functions, i.e., providing direct protection against the extracellular parasites (helminths), but this protective immunity occasionally leads to adverse reactions, such as an allergic response [6-8]. The protective functions of Th2 immunity for pathogen clearance are mediated by the induction of Th2 cytokines (interleukin 4 (IL-4), 5 (IL-5), 6 (IL-6), 10 (IL-10), and 13 (IL-13)) and the recruitment of B cells and eosinophils, while allergic responses are mediated by hypersecretion of IgE from B cells and histamines from mast cells and basophils. Genetic and environmental factors have also been considered to influence the Th2 immune response. Environmental factors include pathogens (bacteria, viruses, fungi, and parasites), foods, and allergens (house dust mites (HDMs), pollens, etc.), whereas genetic factors include the specific genes of DCs 
essential for induction of Th2 immunity. Other factors, such as hormones and lipids, also affect Th2 immunity, but details on these subjects are beyond the scope of this review. This review mainly covers DC-mediated Th2 immunity.

DCs are the first lines of immune defense that come into play once encountered with a foreign antigen and decide whether to tolerate or elicit a strong immune response against it. If the response has already intensified, the immune system must decide what kind of response is appropriate to clear the pathogens. To accomplish this task, DCs engulf and present these antigens via cross-presentation machinery to $\mathrm{CD}^{+}$naïve $\mathrm{T}$ or $\mathrm{CD} 8^{+} \mathrm{T}$ cells (Figure 1), leading to the birth of a specific T-cell subset, like $\mathrm{T}$ helper types 1 (Th1), 2 (Th2), and 17 (Th17), and T regulatory (Treg) subsets or cytotoxic $\mathrm{T}$ lymphocytes (CTLs) to orchestrate immune responses in both humans and mice [9]. A pool of cytokines released during this process actually governs the fates of these $\mathrm{T}$ cells to acquire specific T-cell polarity. Differentiation of Th1 cells is triggered by interleukin 12 (IL-12) and characterized by high-level secretion of cytokines: Interferon gamma (IFN- $\gamma$ ), interleukin 2 (IL-2), and lymphotoxin, which recruits macrophages, B-lymphocytes, $\mathrm{CD} 8^{+} \mathrm{T}$ cells, natural killer (NK) cells, and neutrophils to the site of infection to impart protective Th1 immunity in both humans and mice [10]. Conversely, Th2 cells are triggered by IL- 4 and characterized by high-level secretion of IL-4, IL-5, and IL-13, which activate $\mathrm{B}$ cells to produce immunoglobulin E (IgE) and recruit basophils to mediate Th2-specific immune responses in both humans and mice [11]. Despite the crucial role of T-cell subsets in host defense, they are also associated with severe immune pathologies, including hypersensitivity, tumorigenesis, and autoimmunity [12]. The mechanisms controlling the differentiation of Th1, Th17, and Treg cells are well described. However, the details of Th2 differentiation by specific subsets of DCs remain controversial. Gao et al. (2013) investigated the role of the IRF4 ${ }^{+}$DC subset in initiating the Th2 response in mice [13]. Murphy et al. (2015) suggested that a Klf4-expressing DC subset is required for Th2 responses in mice [14]. A recent study by Ahmed et al. (2017) has shown that a DC subset expressing SH2 domain-containing adaptor protein B (SHB) ensures Th2 homeostasis by regulating DC-mediated Th2 immunity in an atopic dermatitis (AD) mouse model [15]. These findings prompted us to investigate the role of these genes in DC-mediated Th2 immunity. In this review, we discuss DC subsets and genes of interest in DCs essential for induction of Th2 immune responses in the context of allergic diseases and illustrate the well-coordinated interplay of different signaling pathways, such as transcription factors, cytokines, epigenetics, and microRNAs, which are essential to obtain an optimal Th2 response.

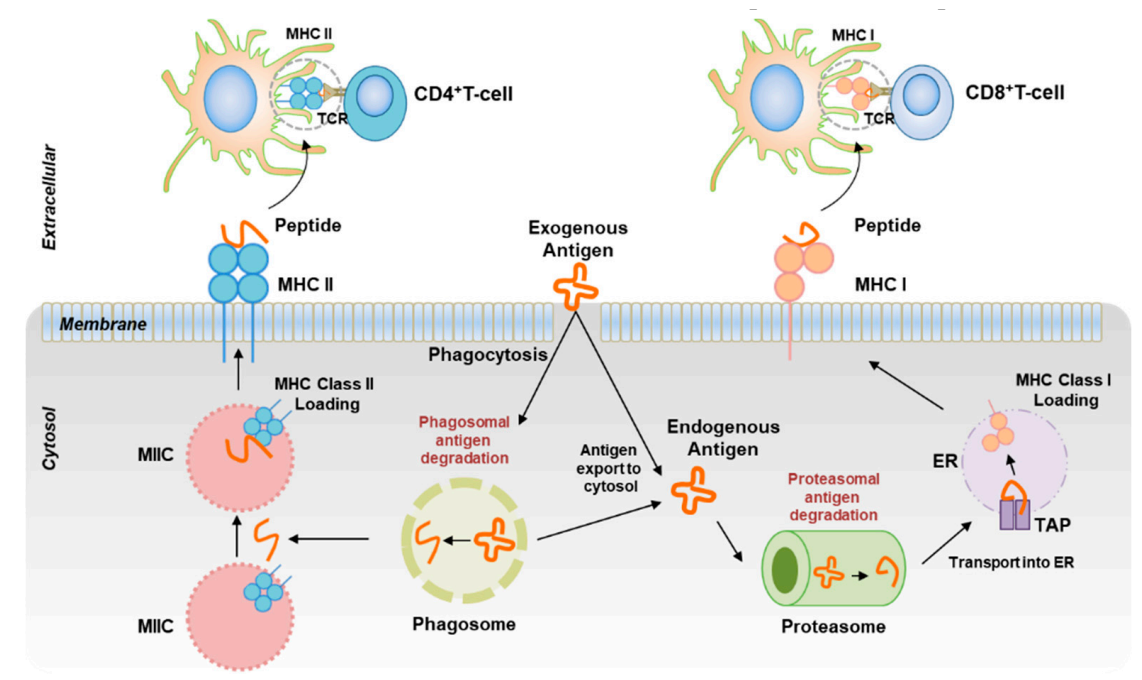

Figure 1. Schematic diagram for the cross-presentation machinery of DCs. DCs take up extracellular antigen, process it to antigenic peptides, and present these peptides not only with MHC II through the MIIC to CD4 ${ }^{+} \mathrm{T}$ cells (left), but also with MHC I through proteasome and the TAP/ER pathway to CD8 ${ }^{+} \mathrm{T}$ cells (right). 


\section{T Cell Immunity}

\subsection{T Cell Development from Nä̈ve T Cells}

The two major subsets of T lymphocytes, $\mathrm{CD} 4^{+} \mathrm{T}$ helper (Th) and CD8 ${ }^{+}$cytotoxic T lymphocytes (CTL), are distinguished by specific cell surface markers. DCs have the ability to differentiate naïve $\mathrm{CD}^{+} \mathrm{T}$ cells into different Th subsets, which requires three important signals (signal 1, 2, and 3) [16]. The signal 1 initiates the primary binding of APCs to antigen-specific $\mathrm{T}$ cells through interaction between antigenic peptide-loaded MHC II (class II major histocompatibility complex) and T-cell receptor (TCR) to induce the antigen-specific $\mathrm{T}$ cell response. The signal 2 is involved in $\mathrm{T}$ cell stimulation via interaction between the B7 costimulatory molecules on the DCs and CD28 on T cells. The third signal constitutes polarizing cytokines crucial for $\mathrm{CD} 4{ }^{+} \mathrm{T}$-cell differentiation into functional effector T-cell subsets. The signals obtained from the polarizing cytokines lead to the expression of specific transcription factors that direct the expression of effector cytokines and thus specialized Th-cell subsets, such as T-bet ${ }^{+}$IFN- $\gamma^{+}$Th1, GATA- $3^{+}$IL- $4^{+}$Th2, STAT6 ${ }^{+}$IL- $9^{+}$Th9, STAT3 ${ }^{+}$Ror $\mathrm{t}^{+}$IL-17 $^{+}$Th17, and Foxp $3^{+}$STAT5 $^{+} \mathrm{CD}^{2} 5^{+}$Treg cells (Figure 2) $[10,17]$. Th9 cells play a role in defense against helminth infections, in allergic responses, in autoimmunity, and tumor suppression [18], but their functions are still unclear. Th17 cells are involved in maintaining mucosal barriers and contributing to pathogen clearance at mucosal surfaces, but they have also been implicated in autoimmune and inflammatory disorders $[19,20]$. Treg cells modulate the immune system by suppressing or downregulating induction and proliferation of effector T cells, thus leading to maintenance of self-tolerance [21] and prevention of autoimmune disease [22]. Among these Th subsets, we expand this review to the Th1 and Th2, and finally more to the Th2 immunity.

\subsection{Th1 and Th2 Responses}

Each T-cell subset originating from naïve $\mathrm{T}$ cells takes charge of a specialized function and is recognized by specific characteristics. Th1 cells are characterized by high-level expression of IFN- $\gamma$, IL-2, lymphotoxin $\alpha$, and tumor necrosis factor-beta (TNF- $\beta$ ) in response to IL-12 signaling. Th1 cells induced against intracellular parasites, such as protozoa, bacteria, viruses, and fungi, which recruit macrophages, neutrophils, NK cells, cytotoxic T-cells, B cells, and microglial-like effector cells to eliminate invaders by activating cell-mediated immune responses. Over-activation of Th1 cells leads to organ-specific autoimmune diseases, such as hypersensitivity, arthritis, and type 1 diabetes. The major transcription factors initiating Th1 cell differentiation are T-bet, STAT4, STAT1, Runx 3, Eomes, Hlx, etc. [12]. Th2 cells, in contrast, are characterized by expression of IL-4, IL-5, and IL-13 in response to IL-4 signaling. Th2 cells induced against extracellular parasites, mainly helminths and allergens, recruit B cells to produce IgE antibodies, basophils, eosinophils, and mast cells to eliminate the parasites by activating humoral and cell-mediated immune responses. Over-activation of Th2 immunity can lead to systemic autoimmune inflammatory diseases, such as allergies and AD. The major transcription factors initiating Th2 cell differentiation are GATA3, STAT6, STAT5, STAT3, Gfi-1, c-Maf, and IRF4 [23], as summarized in Figure 2.

\subsection{Special Characteristics of Th2 Response}

IL-4 is the key cytokine in Th2 immunity, but for many years, immunologists faced a "Th2 paradox." Th2 development from naïve T cells requires activation of signal transducer and activator of transcription 6 (STAT6) downstream of the IL-4 receptor-signaling pathway, but the only known source of IL-4 was the Th2 cell itself. Today, however, other cell types, such as basophils [24,25], mast cells [26,27], and NKT cells [28], are known to serve IL-4 sources in both humans and mice. Among the transcription factors involved in developing T-cell subsets, GATA3 [29] and STAT6 [30] are the most important for Th2 differentiation from naïve $\mathrm{CD} 4^{+} \mathrm{T}$ cells in both humans and mice. Two major signaling pathways, IL-2/STAT5 and IL-4/STAT6, play a crucial role in Th2 differentiation. IL-2/STAT5 signaling implies that IL-2 receptor signaling initiates STAT5 activation, leading to the expression of 
IL-4 [12]. In the following IL-4/STAT6 pathway, IL-4 receptor signaling entails phosphorylation of STAT6 monomers, resulting in dimerization and translocation into the nucleus. In the nucleus, STAT6 dimers activate GATA3, which binds to the promoters of IL-4, IL-5, and IL-13, leading to the expression of these Th2 driving cytokines in both humans and mice [31].
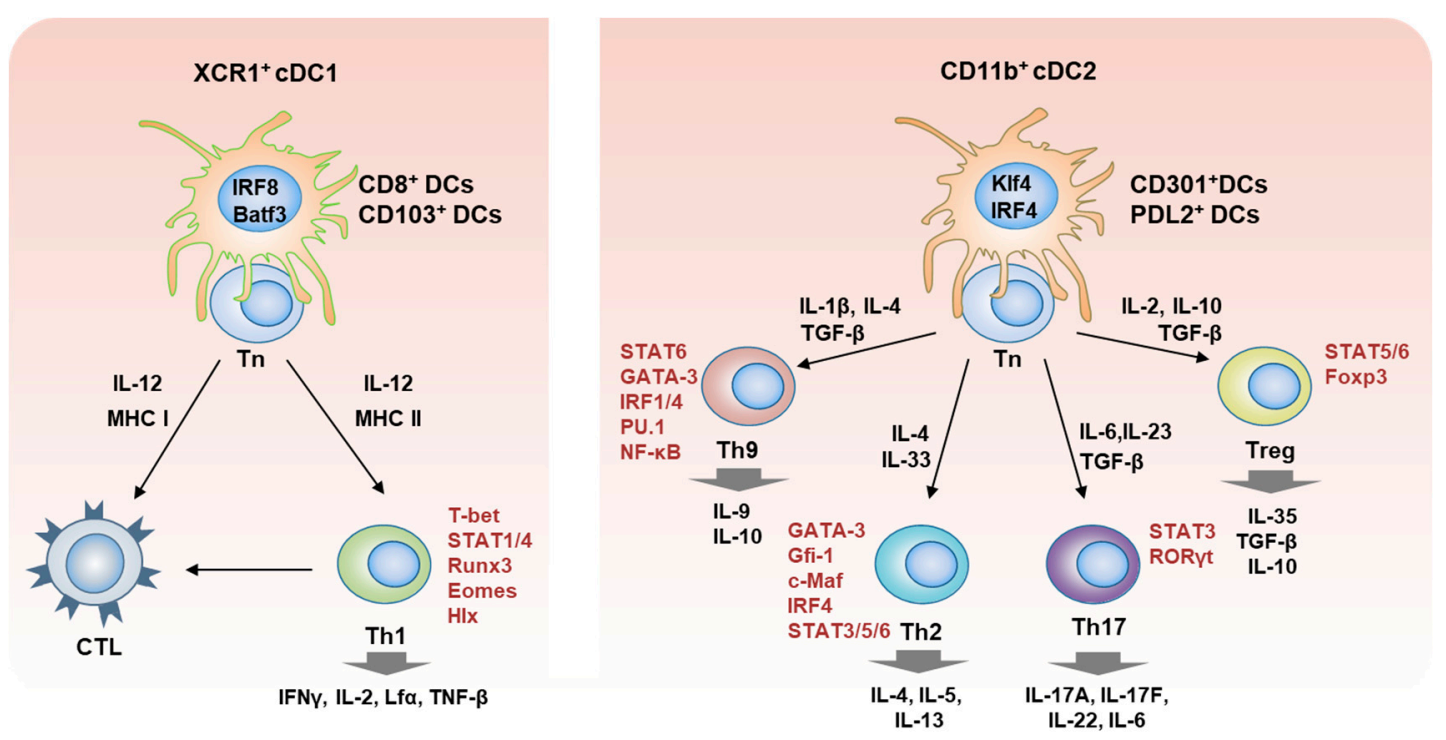

Figure 2. Schematic diagram for the involvement of $\mathrm{cDC} 1$ and $\mathrm{cDC} 2$ subsets in the T cell development. The XCR1 ${ }^{+}$cDC1, having major transcription factors, IRF8 and Batf3, are involved in the differentiation of naïve T cells into cytotoxic T lymphocytes (CTL) and Th1 cells with the CDC1 cytokine, IL-12 (left). Whereas, CD11b ${ }^{+}$cDC2 known by their IRF4 and Klf4 facilitate the T cell development into Th2, Th9, Th17, and Treg cells with cDC2 cytokines (right). Key transcription factors mediating the development of each $\mathrm{T}$ cell subset are indicated in red. Each $\mathrm{T}$ cell subset secretes the effector cytokines as described.

\section{Immune Cells Other than DCs and Cytokines in Polarizing Th2 Immunity}

\subsection{Basophils and Mast Cells}

Basophils and mast cells are the major source of IL-4 inducers in mediating Th2 immunity. Basophils comprise $0.5 \%$ to $1 \%$ of total blood cells categorized as granulocytes. They contain inflammatory cytokines, such as histamines and heparins, which are known to cause harmful allergic reactions, but also help eliminate parasitic infections. Nakanishi et al. (2010) [32,33] proposed that basophils act as APCs and trigger Th2 immune responses through three pathways: First, by secreting IL-4 upon binding of allergen-IgE to its FceRI surface receptor; second, through IL-3- and IL-33-dependent stimulation of basophils to secrete IL-4; and third, through pathogen-associated molecular pattern (PAMP) and toll-like receptor (TLR) ligand-associated direct stimulation of basophils in secreting IL-4. Another study with CD11c- DTR (diphtheria toxin receptor) mice showed that DC alone is not sufficient to induce a Th2 immune response, but it requires cooperation with basophils to enhance IL-4 production in response to protease allergen papain [34-36]. Collectively, these findings suggest that basophils behave as an accessory cell to support DCs in inducing Th2 immune response by serving IL-4 cytokines.

\subsection{Innate Lymphoid Cells (ILCs)}

ILCs, which consist of three subsets derived from the same progenitor cells, were recently discovered to be involved in initiating T-cell responses. Among the three groups, only the ILC2 group was found to be involved in Th2 immune responses in response to IL-4, IL-25, and IL-33 [37,38]. It activates in response to parasites and allergens and contributes to allergic inflammatory diseases, such as asthma, chronic rhinitis, and AD [3]. Recently Kim et al. (2013) found that ILC2 cells are present on healthy skin as well as lesional skin, which contributes to inflammatory responses in AD. The ILC2 
cells on AD lesion skin are characterized by high-level expression of CD25/IL-33R/CRTH2/CD161, which are found at low levels in healthy skin [39].

\subsection{Epithelial Cells (ECs)}

ECs in the outer barrier of our body constantly encounter invasive or inhaled pathogens and allergens, resulting in the production of thymic stromal lymphopoietin (TSLP), IL-25 (or IL-17E), and IL-33. These cytokines induce APCs, leading to activation of Th2 immune responses. In the thymus, TSLP is important for lymphocyte development, but when secreted by ECs it induces Th2 immune responses [40].

\subsection{Th2-Inducing Cytokines Other than IL-4}

TSLP is expressed in several organs, including the intestines, lungs, tonsils, and thymus, and primes DCs to enhance Th2 differentiation while inhibiting Th1-related IFN $\gamma$ and IL-12 cytokines. TSLP can also activate basophils and mast cells in both humans and mice [10]. TSLP receptor-deficient mice have shown impaired Th2 responses [41], while excessive production of TSLP has been shown to increase asthmatic reactions [42]. TSLP is also known to activate TCRs by interacting with OX40 ligands, resulting in enhanced Th2 polarization [43]. Increased levels of TSLP are associated with rheumatoid arthritis and atopic diseases [44,45]. In addition to TSLP, ECs also secrete other cytokines, such as IL-25 and IL-33, which contribute to Th2 responses. IL-25, also known as IL-17E, is not only expressed in lung ECs, but also in eosinophils, basophils, mast cells, macrophages, and Th2 cells. Enhanced expression of IL-25 is reportedly associated with asthma, AD, and allergic airway inflammation in both humans and mice [46,47]. Inhalation and hypersecretion of IL-25 in airway ECs promotes Th2 inflammation in the lungs [48]. IL-25 secreted from lung ECs stimulates DCs to activate Th2 responses by upregulating expression of Jagged 1 (Notch ligand) [49]. In contrast to the role of IL-25 in directly activating $\mathrm{CD}^{+} \mathrm{T}$ cells toward the Th2 lineage, it has also been found in inhibiting Th1 and Th17 differentiation. In autoimmune inflammation, IL-25 suppresses Th17-mediated inflammation [50] and gut inflammation by inhibiting Th1 responses [51]. In humans, TSLP also activates DCs to promote Th2 immune response via IL-25 signaling [47]. The IL-25-- mouse shows susceptibility to autoimmune encephalitis and severe disease progression, including failure to eliminate the helminth, Nippostrongylus brasiliensis, due to poor Th2 response [51,52]. Collectively, these results suggest that cytokines secreted from ECs favor the Th2 specific immune response. IL-33 is a member of the IL-1 family and is a ligand for receptor ST2 and functions as an alarmin to activate other cell types. IL-33 inhalation potently drives production of Th2 cytokines (e.g., IL-4), resulting in activation of Th2 immune responses in both human and mouse, as shown by an increase in mucus production, IgE secretion, and eosinophilia [53]. IL-33 activates mouse DCs to stimulate the Th2 immune response during allergic airway inflammation [54,55]. IL-33 also stimulates mast cells to produce TSLP [56] and basophils to enhance the release of histamines and IL-4 in the presence of IL-3 [57], leading to activation of mast cell-basophil-driven anaphylaxis and inflammation [58]. The synergistic effect of IL-33 and TSLP has been shown to enhance the production of Th2-related chemokines and cytokines by mast cells. Collectively, IL-33, IL-25, and TSLP secreted from different cell types induce the production of Th2-related cytokines, leading to allergic inflammatory diseases, such as AD and allergic asthma [46].

\section{Dendritic Cell Subsets and Th2 Immunity}

Th2 immunity is an important defense mechanism against extracellular parasites and allergens. DCs can generate effector T-cell subsets from naïve T cells specialized for specific immune responses and are therefore considered "master regulators" of immune responses because they have the ability to initiate and control the adaptive immune response. DCs comprise a heterogeneous group of cells originating from bone-marrow hematopoietic stem cells (HSC) and early myeloid progenitors (EMP) in the blood, tissues, and lymphoid organs. They are generally classified on the basis of their locations, 
functions, and cell surface markers. HSCs give rise to conventional/classical DC1 (cDC1) and DC2 (cDC2), plasmacytoid DCs (pDCs), and monocyte-derived DCs (Mo-DCs) (Table 1).

Table 1. Dendritic cell subtypes in the human and mouse.

\begin{tabular}{|c|c|c|c|c|}
\hline \multirow[b]{2}{*}{ Classification } & \multicolumn{2}{|l|}{ Human } & \multicolumn{2}{|c|}{ Mouse } \\
\hline & Main Surface Marker & Major TcFs & Main Surface Marker & Major TcFs \\
\hline pDC & $\begin{array}{c}\text { CD123(IL-3R), CD45R, } \\
\text { CD303(CLEC4C) } \\
\text { CD304(BDCA-34), } \\
\text { CD85k(ILT3), CD85g(ILT7), } \\
\text { FCER1, BTLA1, CD300A }\end{array}$ & $\begin{array}{c}\text { TCF4/E2-E, } \\
\text { IRF4/7/8, Zeb2 }\end{array}$ & $\begin{array}{l}\text { CD317, Siglec-H, } \\
\text { CD45R, CD45RA }\end{array}$ & TCF4/E2-E, IRF8 \\
\hline cDC1 & $\begin{array}{c}\text { CD141(BDCA-3), CD13, } \\
\text { CD33, CLEC9A, } \\
\text { CADM1(NECL2), BTLA, } \\
\text { XCR1 }\end{array}$ & BATF3, IRF8, ID2 & $\begin{array}{l}\text { CD8 } \alpha, \text { CD103, } \\
\text { DEC205, XCR1 }\end{array}$ & $\begin{array}{l}\text { BATF3, IRF8, ID2, } \\
\text { BCL6, PU.1, E4BP4 }\end{array}$ \\
\hline cDC2 & $\begin{array}{c}\text { CD1c, CD2, FC } \varepsilon R 1, C D 11 b \\
\text { CD11c, CD1a }\end{array}$ & $\begin{array}{l}\text { ID2, IRF4, KLF4, } \\
\text { Notch2, RBPJ }\end{array}$ & $\begin{array}{l}\text { CD11b, SIRP } \alpha \\
\text { CD301b, PD-L2 }\end{array}$ & $\begin{array}{c}\text { IRF4, KLF4, } \\
\text { Notch2, ID2, Zeb2, } \\
\text { RelB, SHB, STAT5 }\end{array}$ \\
\hline Mo-DC & $\begin{array}{l}\text { CD1a, CD1c, CD11b, CD14, } \\
\text { CD16, CD19, CD20, FC } \varepsilon \text { RI } \alpha\end{array}$ & MAFB, KLF4 & $\begin{array}{l}\text { CD11b, CD209, Ly6C, } \\
\text { Ly6G, CD64, F4/80 }\end{array}$ & IRF4, Zbtb46 \\
\hline
\end{tabular}

EMPs give rise to monocyte-derived macrophages and long-lived resident macrophages. Development of the $\mathrm{XCR} 1^{+} \mathrm{cDC} 1$ subset $\left(\mathrm{CD} 8 \alpha^{+} \mathrm{cDCs}\right.$ and $\left.\mathrm{CD} 103^{+} \mathrm{cDCs}\right)$ is dependent on IRF8, ID2, and Batf3 transcription factors. Development of $\mathrm{CD} 172^{+} \mathrm{CD} 11 \mathrm{~b}^{+} \mathrm{CDC} 2$ subsets is dependent on Klf4, IRF4, ID2, ZEB2, RelB, and Notch2 transcription factors. The IRF8-dependent CDC1 subset presents antigens to $\mathrm{CD} 8^{+} \mathrm{T}$ (CTL) cells through MHC I, mainly involved in promoting anti-viral and Th1 cell response, whereas IRF4-dependent $\mathrm{CDC} 2$ subsets present to $\mathrm{CD} 4^{+} \mathrm{T}$ cells through MHC II with the ability to favor polarization toward Th2, Th9, Th17, and Treg cells [14,59] (Figure 2). Among the IRF4 ${ }^{+}$cDC2 group, three subsets $\left(\mathrm{CD} 301 \mathrm{~b}^{+} \mathrm{DCs}\right.$, PDL2 ${ }^{+} \mathrm{DCs}$, and CD11b $\left.\mathrm{b}^{+} \mathrm{DCs}\right)$ are well established to be associated with induction of the Th2 immune response in mice, as summarized by $\mathrm{Na}$ et al. (2016) [3]. The subsets are located mainly in the skin, lung, and spleen. Mouse CD301b ${ }^{+}$DCs are a skin-resident DC subset that plays a crucial role in the Th2-mediated contact hypersensitivity response in the skin $[17,59]$. Mouse PDL2 ${ }^{+}$DCs are enriched in the lung and the draining lymph nodes (dLNs) of the skin and intestine and are involved in allergic inflammation by enhancement of Th2 immunity [60]. Neither type of $\mathrm{CDC} 2$ subset induces differentiation or development of Th2 immunity, but enhances Th2 responses by activating effector and memory $\mathrm{T}$ cells $[3,59]$. CD11b $\mathrm{b}^{+} \mathrm{DCs}$, however, are involved in the development of Th2 responses from naïve T cells in the regional $\mathrm{LN}$ upon activation and CCR7-dependent migration $[15,61,62]$. In addition, CXCR5 ${ }^{+}$DCs also play an important role in inducing Th2 immunity in intestinal nematode infection [63]. Mayer et al. (2017) identified two different populations of $\mathrm{CD} 11 \mathrm{~b}^{+} \mathrm{DC}$ in the gut mucosal tissue, which induce Th2 response; $\mathrm{CD} 11 \mathrm{~b}^{+}$ $\mathrm{CD}_{103}{ }^{+} \mathrm{DC}$ in the small intestine and CD11b ${ }^{+} \mathrm{CD} 103^{-} \mathrm{DCs}$ in the colon [62]. On the other hand, it is well established that in vitro-generated human Mo-DCs and mouse BMDCs can induce both $\mathrm{CD}^{+}$and $\mathrm{CD}^{+} \mathrm{T}$ cell responses through their cross-presenting capacity in nature. However, when inoculated in vivo, DC vaccines induce different polarization of CD4 vs. CD8 T cell responses in both the human and mouse, depending on the maturation conditions (hormones, cytokines, and TLR/RLR ligands) and pulsed antigens during the DC development even in the presence of same cytokines, like GM-CSF and/or IL-4 [64,65]. In addition, mouse conventional DC1 (cDC1) can also induce Th2 responses when exposed to allergens in the lung [66], and alpha-myosin-presenting CDC2 was also reported to induce Th1/Th17 in an experimental autoimmune myocarditis model [67]. 


\section{DC-Mediated Th2 Immunity}

Th2 immunity has evolved to clear multicellular pathogens. For example, because helminths are eukaryotic organisms, their physiology resembles that of humans more than it does that of unicellular organisms. Therefore, it is logical to expect that the recognition of helminths becomes more difficult for the human immune system. DCs are important APCs that can recognize such pathogens and trigger a specific Th2 immune response. IL-4 is the major cytokine required for Th2 polarization, which provides protective immunity against multicellular parasites in both humans and mice [68,69]. However, an excessive Th2 response can lead to allergic reactions. Genetic (intrinsic) and environmental (extrinsic) factors affect DC development, leading to the induction of DC-mediated Th2 responses [70]. Genetic factors comprise $\mathrm{CDC} 2$-specific surface molecules, certain genes (transcription factors, micro RNA, and epigenetics) required for the development of $\mathrm{CDC} 2$ from $\mathrm{DC}$ precursor cells, and other genes involved in the control of cDC2 development. Environmental factors also induce Th2 immunity by affecting cDC2 development. Helminths, HDMs, bacteria- or virus-derived PAMPs, allergens, and cytokines are all involved in DC-mediated Th2 immunity [71]. In this section, typical genetic and environmental factors affecting $\mathrm{CDC} 2$ development are discussed in connection with Th2 polarization and allergic inflammation (Figure 3).
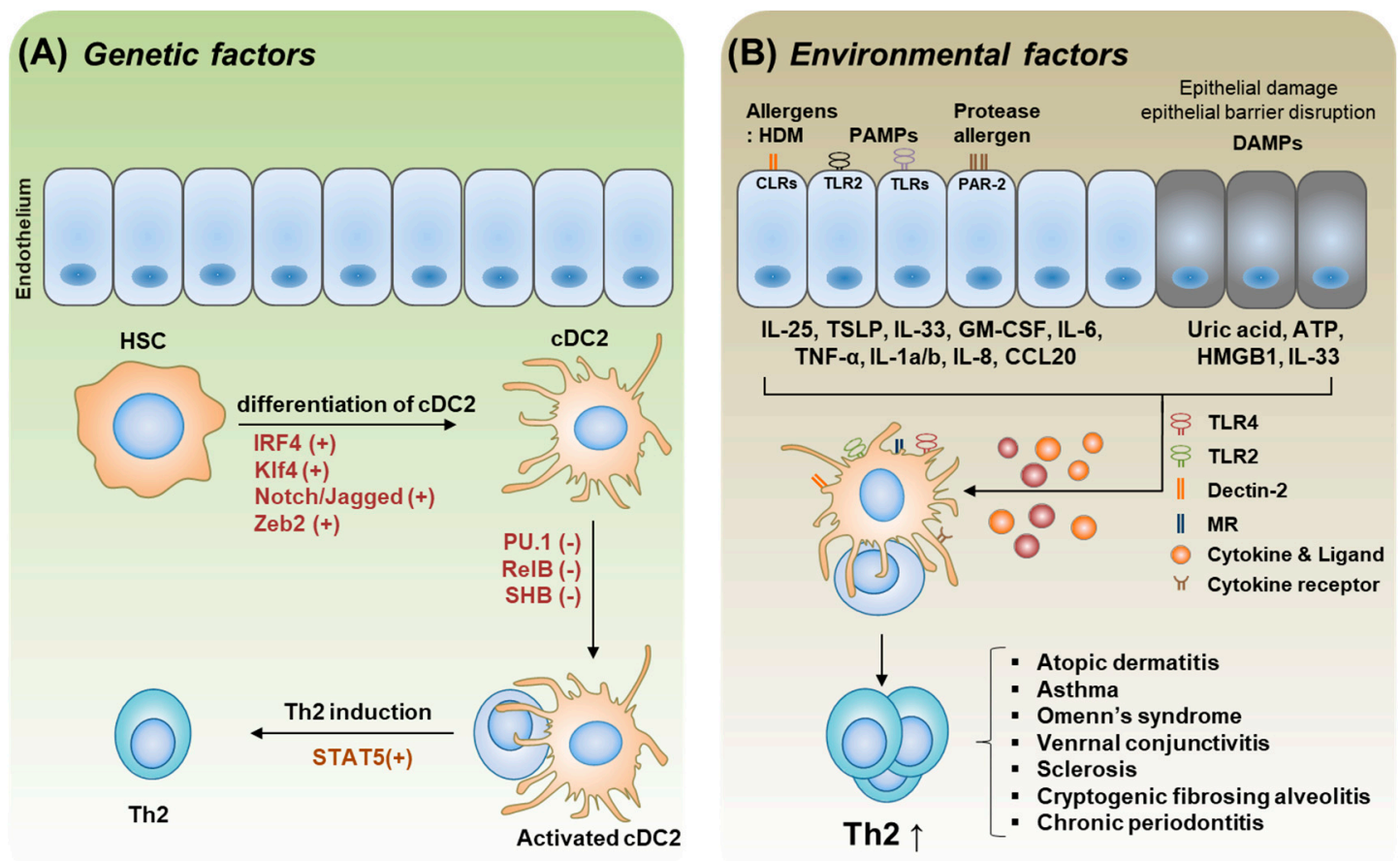

Figure 3. Genetic factors and environmental factors which are involved in the development of the cDC2 phenotype, eventually mediating Th2 polarization. (A). Genetic factors involved in each stage of cDC2 differentiation and cDC2-mediated Th2 development. Major transcription factors required for $\mathrm{CDC} 2$ development are marked in red and (+) as positive regulators, and (-) as negative regulators in the development of cDC2 and in controlling DC-mediated Th2 polarization. (B). Environmental factors affecting $\mathrm{CDC} 2$ priming and $\mathrm{CDC} 2$-mediated Th2 polarization and associated immune disorders. Allergens, PAMPs, and DAMPs, and their receptors on the ECs and DCs are indicated. Cytokines and ligand molecules secreted from damaged or primed ECs and their recognition receptors on DCs are indicated. Primed cDCs stimulate Th2 responses, occasionally leading to Th2 immune disorders. Details are described in the text. 


\section{Genetic Factors Required for cDC2 Development and Th2 Immunity}

\subsection{Specific Surface Features of Th2-Inducing DCs}

To initiate a Th2 immune response from naïve $\mathrm{CD} 4^{+} \mathrm{T}$ cells, DCs require the expression of specific surface receptors to recognize and present helminth-derived antigens and allergens to Th2 cells. Chemokine receptor, CXCR5 (CXCL13) [72,73]; cytokine-receptors, TSLP receptor (CRLF2 and IL-7R $\alpha$ ) [74,75], IL-25R, and IL-33R (ST2); inducible costimulatory molecules ICOS (B7h) [76], OX40/OX40L [75], CD30/CD30L [77], and TIM1/TIM4 [78,79]; pattern recognition receptors (PRRs; TLR2, 3 and 4) [71]; c-type lectin receptors (Dectin-2, MGL, MR, DC-SIGN) [80,81]; RIG-l-like receptors (MDA5, LGP2) [82]; and protease-activated receptors (PAR 1-3) [83] are preferentially expressed on Th2-inducing DCs in both the human and mouse. Damage-associated molecular patterns (DAMP) receptors [84], including complement receptors (hCR1, hCR2, hCR3, $\mathrm{mC} 3 \mathrm{aR}, \mathrm{mC5}$ aR), prostanoid receptors (DP1, EP2, EP4, IP) [85], neuropeptide receptors (NK1, CGRPR) [86], purinergic receptors (P2X, P2Y) [87], HMGB1 receptor (RAGE) [88], and heat shock protein receptors (CD14, CD36, CD91) [89,90], are also preferentially expressed on Th2-inducing DCs.

\subsection{Transcription Factors (TcFs)}

Among the DC subset, the $\mathrm{CDC} 2$ subset plays a major role in inducing Th2 immunity. Several $\mathrm{TcFs}$ are required for the proper development of cDC2. In this section, we summarize several TcFs, which are essential for $\mathrm{cDC} 2$ development leading to induction of Th2 response. Kruppel-like factor 4 (Klf4) and interferon regulatory factor 4 (IRF-4) are well-established TcFs for cDC2 development from pre-cDCs. CD11c-conditional Klf4 depleted mice showed impaired Th2 response against parasitic infection (S. mansoni) and HDM, probably due to the reduced populations of the cDC2 subset and $\mathrm{IRF}^{+}$pre-DCs [14]. Recently Gao et al. (2013) [13] identified that the IRF4 ${ }^{+}$cDC2 subset is required for Th2 immunity against a protease allergen and N. brasiliensis infection. STAT5 was also reported to be involved in CDC2-mediated Th2 immunity. Bell et al. found that the DC-specific deletion of STAT5 had no effect on DC development, but impaired Th2-mediated allergic responses in skin and lungs $[91,92]$. The proposed mechanism suggested that loss of STAT5 in DCs leads to the inability to respond to TSLP, resembling the lack of Th2 response in TSLPR ${ }^{-/-}$mice [91,92]. This result indicates that the STAT5-TSLP axis in DCs is critical in promoting Th2 immunity. Notch and Notch ligands expressed in $\mathrm{CDC} 2$ play a crucial role in regulating Th1/Th2 polarization in both the human and mouse [93,94]. Immature DCs constitutively express Jagged-1, which induced $\mathrm{TH} 2$ polarization in $\mathrm{CD}^{+}{ }^{+} \mathrm{T}$ cells while DC-specific Jagged-1 depletion inhibited Th2 polarization in humans [94]. Overexpression of Notch ligand Delta-1 in DCs exerted anti-allergic effects on Th2-mediated allergic asthma in mice [95]. This result supports a previous report that up-regulation of Notch ligands Delta- 1 and Delta-4 in DCs inhibits Th2 development via the MyD88-dependent pathway [93]. Two independent studies suggest that DCs expressing TcF PU.1 play a crucial role in mediating Th1/Th2 responses. In one study, DC-specific PU.1-deficient mice induced a Th1toTh2 shift in T cell response, resulting in reduced intestinal transplant rejection in female Lewis-recipient rats due to the mixed chimerism induced by PU.1-silenced DCs [96]. In another study, the negative effect of PU.1-expressing DCs in mediating Th2 responses in mice was revealed to be due to the inhibition of GATA3 [97]. The mechanistic justification reveals PU.1 binds to a GATA3 promoter, which leads to the suppression of GATA3 expression, and high-level recruitment of the H3K4me3 heterochromatin mark at the promoter, resulting in suppression of Th2 cytokine (IL-5 and IL-13) expression. Zinc finger E-box-binding homeobox 2 (Zeb2) is an essential TcF in mediating cDC2 development from pre-cDCs. Zeb2 is expressed at the pre-pDC and pre-cDC stage and highly expressed in mature pDCs and cDC2s. CD11c-specific Zeb2-knockout mice showed decreased populations of $\mathrm{pDCs}$ and $\mathrm{CDC} 2$, but with increased population of $\mathrm{CDC} 1$, while, conversely, mice overexpressing Zeb2 had reduced the population of $\mathrm{cDC} 1$ by Zeb2-mediated targeting of Id2, a key TcF of cDC1 [98]. RelB, a member of the nuclear factor kappa-light-chain-enhancer of activated B cell (NF-kB) family is an essential TcF for DC development, maturation, and function. 
Adoptive transfer of RelB-deficient DCs showed the increased allergic airway inflammation with an increase in Th2-associated cytokines, IL-4, IL-5, and IL-13, in recipient mice, indicating that RelB in DCs is involved in controlling DC-mediated Th2 immune responses [99].

\subsection{Genetic Factors Other than TcFs Involved in Th2-Inducing DC Development}

Mind-bomb-1 (Mib-1), an E3 ubiquitin-protein ligase involved in regulating cell apoptosis, is a critical regulator of Notch ligands for the activation of Notch signaling, increasing gradually as precursor cells differentiate into DCs in mice. Mib-1-depleted DCs were not effective at stimulating Th2 proliferation in co-culture with T cells [100], suggesting that the Mib-1 expressed in DCs is critical for Notch-mediated Th2 differentiation. However, certain genetic factors are involved in controlling DC-mediated Th2 responses as a negative regulator. DCs deficient in expressing myeloid differentiation primary response 88 (MyD88) promoted Th2 response with a significant decrease in Th1 and Th17 cells, leading to enhanced pancreatic inflammation in both humans and mice [101]. Spontaneous mutations of the SHANK-associated RH domain-interacting protein (Sharpin or Rbckl1, Sipl1) gene in mice induce a Th2 immune response, resulting in systemic inflammation characterized by chronic progressive dermatitis [102]. Studies of the underlying mechanism showed that a Sharpin-deficiency in mice did not alter the distribution and surface phenotype of DC subtypes in the spleen, but did reduce the capacity of DCs to express pro-inflammatory Th1 cytokines and inactivated NF-kB signaling without affecting mitogen-activated protein kinase (MAPK) and TANK-binding kinase 1 signaling pathways, leading to systemic inflammation in Th2-biased response [103]. Additionally, DC-specific depletion of IL-4 receptors reportedly enhances the susceptibility to Leishmanial infection by polarizing the Th2 response [104]. Another study showed that DCs deficient in expressing IL-12 inhibit the progression of autoimmune arthritis by mediating the Th1-to-Th2 shift [105]. Gold et al. (2016) have shown that the DCs expressing SH2-containing inositol 5'-phosphatase 1 (SHIP-1) play a crucial in controlling helminthic infection by inducing a protective Th2 immune response. DC-specific SHIP1-knockout mice were highly susceptible to Trichuris muris infection due to insufficient priming of Th2 response with an increase in IL-12p40 production via negative regulation of the phosphoinositide 3-kinase (PI3K) pathway [106]. Webb et al. (2017) have described the role of type 1 IFN in DC-mediated Th2 polarization upon S. mansoni infection and HDM exposure. The DCs lacking in IFN- $\alpha$ receptor (ifnar1-/-) are unable to initiate Th2 response by impairing the optimal DC phenotype, suggesting its critical role in DC-mediated Th2 immunity [107].

\subsection{Src Homology 2 Domain-Containing Adaptor Protein B (SHB)}

SHB is widely expressed in immune cells and acts as an important regulator in immune cells. SHB is mainly involved in mediating signals from activated tyrosine kinase receptors as well as the TCR in both humans and mice [108-110]. In activated T cells, SHB associates with the $\zeta$-chain of TCR and promotes the phosphorylation and activation of central TCR signaling components [110]. SHB-deficient $\mathrm{CD} 4^{+} \mathrm{T}$ cells were hyper-proliferative and polarized toward a Th2 profile under in vitro stimulation [111]. SHB-knockout mice developed more symptoms of AD, with increased levels of IL-4, IL-5, and IgE, together with epidermal hyperplasia [111]. These data suggest that SHB in T cells plays an important role in controlling Th2-driven inflammation and allergic responses. Recently, Ahmed et al. (2017) reported that SHB is highly expressed in mouse splenic DCs and in vitro-generated BMDCs, and SHB-deficient BMDCs induce Th2 polarization in T/DC co-cultures [15]. When SHB-deficient DCs were inoculated into mice with atopic dermatitis, mice developed more severe disease symptoms [15]. SHB expression in DCs was found to be regulated by p-38-MAPK signaling-mediated Foxa2 expression and activation [15]. Inhibiting the MAPK pathway using a specific inhibitor (SB203580) significantly down-regulated SHB expression and Foxa2 phosphorylation in DCs, and Foxa2 depletion also directly inhibited SHB expression in DCs. SHB-deficient DCs showed typical cDC2 phenotypes: Enhanced expression of MHC-II and costimulatory molecules with no change in MHC-I expression, elevated levels of Th2 cytokines (IL-4 and IL-13) with no increase in IFN- $\gamma$ level, and a decrease in CD4 ${ }^{+} \mathrm{CD} 25^{+} \mathrm{Foxp}^{+}$ 
Treg population in OT-II T-cell/DC co-cultures. The severity and rate of development of AD increased in $\mathrm{BALB} / \mathrm{c}$ mice inoculated with SHB-deficient DCs compared with mice inoculated with normal DCs (Figure 4). Collectively, these studies suggest that SHB expression in DCs is crucial for controlling DC-mediated pathologic Th2 inflammation and allergic disorders.
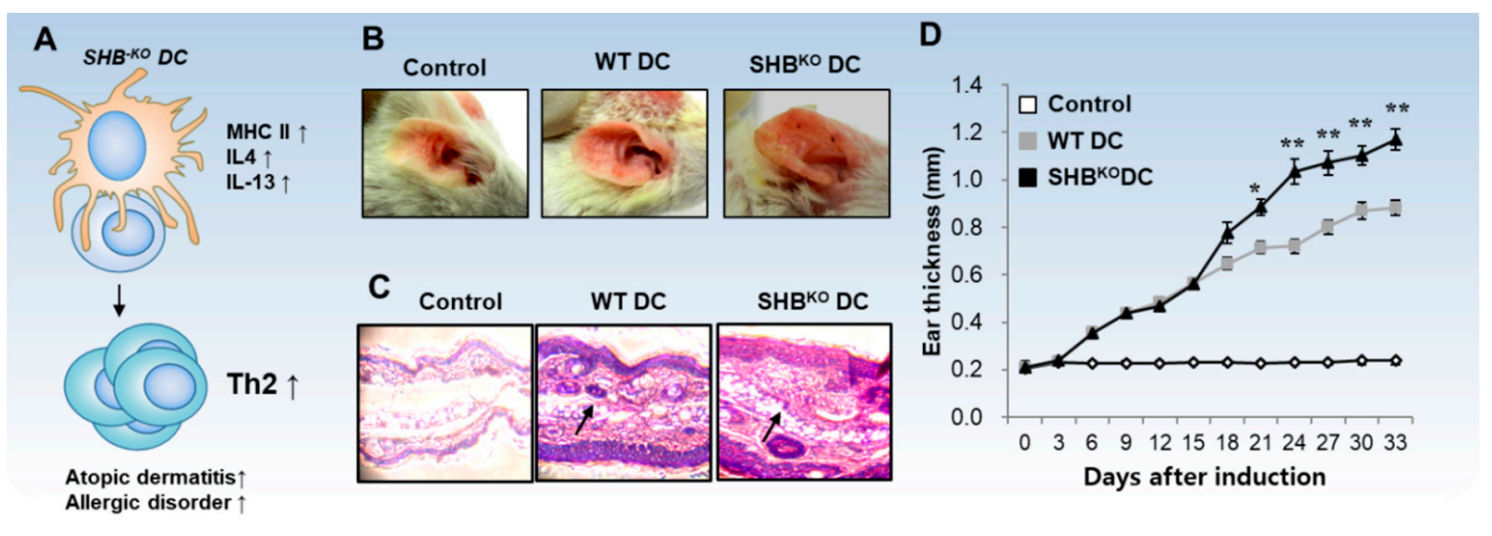

Figure 4. SHB-depleted DCs induce severe symptoms of AD in mice. (A) SHB ${ }^{K O}$ DCs show typical cDC2 phenotypes, which induce Th2 inflammatory disorders. (B) In the mouse AD model, the mice subcutaneously injected with antigen-primed SHB-depleted DCs showed severe AD symptoms as compared with the control mice injected with SHB-normal DCs. (C) Histopathological analysis of $\mathrm{AD}$ after inoculation with normal and $\mathrm{SHB}^{\mathrm{KO}}$ DCs. Arrow indicates the infiltrated immune cells. (D) Graphical representation of ear thickness in mice after inoculation with normal and $\mathrm{SHB}^{\mathrm{KO}} \mathrm{DCs}$. Figure source Ahmed et al. (2017) [15].

\subsection{Epigenetic Factors}

Epigenetic factors also contribute to allergic reactions via DC-mediated Th2 response. Alexey et al. (2010) [112] found that the DNA methylation pattern in DCs causes allergic reactions by enhancing Th 2 cells' response in mice. They found that a neonate from an asthmatic mother is more susceptible to allergic responses compared with newborns from a control mother. When they transferred the DCs from the newborn of the asthmatic mother into normal recipient mice, airway responsiveness upon ovalbumin challenge increased significantly. Epigenetic analysis of the neonates born to an asthmatic mother revealed high levels of DNA methylation from birth. This indicates that, even with the identical genomic constitution, DNA methylation in DCs may cause an allergic response by enhancing Th2 response. Another study showed that methyl-CpG-binding protein (Mbd2) epigenetically controls DC-mediated Th2 immunity in mice [113], revealing that DCs' lack of Mbd2 expression could not induce appropriate Th2 response against helminthic (S. mansoni) infection due to the impairment of Mbd2-mediated H3K9/K14 acetylation, leading to reduced expression of Th2-inducing genes in DCs.

\subsection{MicroRNA}

MicroRNAs have been associated with several allergic inflammatory disorders, including asthma, eosinophilic esophagitis, and allergic rhinitis as well as AD. However, most studies have been performed in association with T-cell development. Recently, Zech et al. (2015) reported that microRNA-155 (miR-155)-deficient DCs showed limited Th2 priming capacity and failed to induce airway inflammation in allergen-exposed mice due to impairment of the miR-155-mediated purinergic type 2 receptor (P2R) signaling activation, resulting in inhibition of DC chemotaxis and IL-1beta secretion upon stimulation [114]. This means that miR-155 is essential for DC-mediated Th2 inflammatory response. 


\section{Environmental Factors}

Apart from genetic factors, several environmental or extrinsic factors facilitate the DC-mediated Th2 immune responses. Most environmental factors or variables drive the immune system to determine the fate of DC-mediated T cell responses, i.e., whether Th1 or Th2 immune responses are elicited in the body. In in vitro cultures, the antigen dose and the DC/T-cell ratio in the same culture condition also affect the DC-mediated Th2 response. For example, bone marrow-derived mouse myeloid DCs cultured in the presence of high doses of antigen induce Th1 cell development, whereas low antigen doses induce Th2 cell development [115]. Human Mo-DC cultures with naïve T cells at a low ratio (1:300) induce Th2 cells, whereas a high ratio (1:4) favors mixed Th1 and Th2 cell development [116]. In addition, DC maturation conditions also affect Th1/Th2 polarization [117]. Following are some of the environmental factors discussed.

\subsection{Allergens}

Allergens, such as pollens and HDMs, can lead to the induction of Th2 immune responses. Exposure of innate immune cells, i.e., eosinophils, basophils, and inflammatory DCs (iDCs), in the mediastinal draining lymph nodes (dLNs) to HDMs activates the TLR4/MyD88-dependent pathway, which recruits the IL-4 competent Th2 immune response. FceRI ${ }^{+}$iDCs present antigens to T cells after exposure to HDMs and induce Th2 immune responses that lead to features of asthma in mice [3]. A study in mice has shown that following HDM inhalation, blood DCs recognize the HDM antigens via the C-type lectin receptor (CLR) dectin-2, which causes the production of cysteinyl leukotrienes, hence leading to the pro-allergic responses $[118,119]$. Another CLR, the mannose receptor (MR) in DCs, mediates the uptake of HDM allergens and induces Th2 polarization through upregulation of indoleamine 2, 3-dioxygenase activity [120]. The role of DCs has been well-established in association with the mechanism of food allergy. Cow's milk causes allergic reactions in healthy mice when DCs are adoptively transferred from allergic mice [121]. This DC-induced allergy in recipient mice was characterized by the presence of cow's milk-specific immunoglobulins (i.e., $\operatorname{IgE}$ and $\operatorname{IgG}$ ) and by the resistance to apoptosis by milk-specific Th2 cells. This apoptosis-resistance feature of Th2 immune responses has been attributed to the donor-specific DC subsets [122]. In a cholera toxin (CT)-induced food allergy model, oral administration of peanut extract and CT induced a shift of DC subsets toward more $\mathrm{cDC} 2$-type $\left(\mathrm{CD} 11 \mathrm{c}^{+} \mathrm{CD} 11 \mathrm{~b}^{+}\right)$than $\mathrm{CDC} 1$ types $\left(\mathrm{CD} 11 \mathrm{c}^{+} \mathrm{CD} 103^{+}\right)$in the mucosa [123], which mediated CT-induced Th2-skewing via up-regulated OX40L in DCs [124]. In addition, peanut allergen and HDM glycoprotein Ara h1 were observed to bind to a CLR, DC-specific, intercellular adhesion molecule 3-grabbing nonintegrin (DC-SIGN), and stimulate human MoDCs to induce Th2 immunity, but deglycosylated Ara h1 did not show a Th2-skewing effect [122]. It means that allergen-bound carbohydrate structures may act as a Th2-skewing adjuvant.

\subsection{PAMPs and DAMPs}

PAMP molecules in invading microbes are recognized by innate immune cells, such as DCs, via specific pattern recognition receptors (PRRs) and activate the immune system [3]. Studies have shown that the activation of DCs in response to pathogens requires the presence of a PAMP molecule to induce Th1 or Th2 polarization in both humans and mice [125]. For example, the trematode, S. mansoni, lays soluble eggs in mice that contain an antigen with a glycosylated $\mathrm{T} 2$ ribonuclease, termed as omega-1, which activate DCs to induce Th2 immune responses [126]. Omega- 1 drives DC-mediated Th2 polarization by suppressing protein synthesis in DCs after internalization via the mannose receptor [127]. Similarly, lipopolysaccharides (LPS) from gram-negative bacteria are reportedly involved in inducing both Th1 as well as Th2 immune responses based on quantity or dose. A high dose of LPS induces Th1 while a low dose activates the TLR4-dependent pathway in DCs to induce Th2 immune responses [128]. Apart from the PAMPs, certain PRRs, such as TLRs, are also involved in driving Th2 polarization by DCs. Pam-3-Cys, a TLR2 ligand (TLR2L), stimulates DCs via 
TLR2, leading to DC-mediated Th2 immune responses via the ERK-cFos pathway. Following ERK activation by Pam-3-Cys, the TcF cFOS is phosphorylated, which inhibits IL-12p70 expression, leading to the induction of Th2 responses in mice [129]. A nematode glycoprotein excretory-secretory-62 induces DC-mediated Th2 skewing via TLR4 in mice $[130,131]$. Similarly, TLR4-mediated Th2 priming via DCs is also shown by the LNFPIII glycol-conjugate in Schistosoma's soluble egg antigen [132]. Tissue injury or damage provokes the release of the DAMPs, which are known to be potent Th2 inducers [42]. Adjuvant alum and high-mobility group nucleosome binding protein 1 (HMGN1) are well-established DAMP molecules known to induce DC-dependent Th2 polarization [43].

\section{Diseases Associated with DC-Mediated Th2 Immunity}

More than one billion people worldwide are suffering from parasitic infections, helminths, and allergic disorders, such as asthma, allergic rhinitis, food allergies, and eczema [133-135]. Common features of these inflammatory diseases are so-called an allergic or "type 2" immune disorder [136]. A number of animal models have been developed to study the pathogenic mechanism of these allergic diseases and obtain better insight into the orchestration of immune-related pathological mechanisms. Murine models are most frequently used to study the development of allergic sensitization, elicitation, and the potential of immunotherapeutic interventions. However, the results obtained from an animal model must be interpreted with caution, as they may not be applicable to human immune diseases. Diseases associated with Th2 dysfunction in humans include Omenn syndrome [137], asthma [95,138,139], AD [140-142], progressive systemic sclerosis [143], cryptogenic fibrosing alveolitis [144], chronic periodontitis [145], progression to AIDS in HIV infection [146], and tumor progression in both human and mouse models [147]. Among these, typical Th2-mediated immune disorders are discussed in this section.

\subsection{Parasitic Infections}

Parasitic infections, especially helminthic infections, occur in almost one-quarter of the world's population [148]. These helminths elicit the innate immune response system to produce Th2 immune responses against invading parasites. These Th2 cells then secrete their respective cytokines, i.e., IL-4, IL-5, and IL-13. Alongside Th2, these cytokines help promote IgE production by B cells as well as recruit eosinophils and activated macrophages [69]. It has been shown that by depleting the

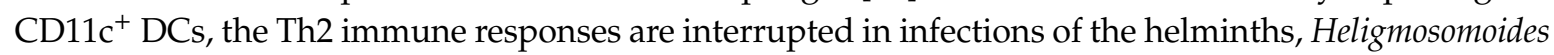
polygyrus and S. mansoni [149-151]. Recent studies have shown that different DC subsets are implicated in Th2 immune responses. Dermal CD301b ${ }^{+}$DCs are involved in Th2 immune responses against $N$. brasiliensis in a mouse model $[13,59]$. Meanwhile, $H$. polygyrus and $N$. brasiliensis, but not T. muris, produce excretory-secretory products and thereby suppress the production of IL-12p40 from DCs in mice [152]. This causes induction of TSLP, which is crucial to induce Th2 immune responses, especially against $T$. muris in a mouse model [153]. Therefore, the impairment of DC in parasitic infections suppresses the Th 2 immunity and rather favors the Th1 immune response in the adaptive immune system. The linking of innate and adaptive immune branches is often associated with the different types of TLRs [154]. When mice were infected by parasites and stimulated via TLR-mediated signaling, DCs secrete pro-inflammatory cytokines and thus upregulate the expression of costimulatory molecules [155]. However, endotoxins, especially LPS, can activate the MyD88-independent pathway. MyD88 is a TLR-associated adaptor protein that is crucial for TLR-mediated cytokine production. However, a recent study has shown that MyD $88^{-/-}$DCs can maintain the expression of costimulatory molecules in response to the endotoxin, and elicit Th2 immune responses in mice [156]. It means that endotoxin can induce DC-mediated Th2 immune disorder via the MyD88-independent pathway

\subsection{Asthma (AS)}

cDC2s play a vital role in generating Th2-mediated immune responses in asthma, including HDM-mediated asthma in a mouse model [157-159]. The cDC2s induce both Th2 and Th17 
differentiation in HDM asthma. Various innate receptors are found on the surfaces of this cDC2 subset that recognize HDM. Dectin-2 is an innate receptor on the surface of cDC2 subset, which recognizes HDM antigens and helps DCs to uptake allergen in mice [118,160]. IRF4-depleted mice show cDC2 deficiency, leading to a reduction of Th2 immune responses $[13,161]$. cDC2s also express OX40L, a TNF family member, which is important for the induction of Th2-mediated asthma. HDM-induced IL-33 production in neonatal mice inhibits expression of IL-12p35 and induces expression of OX40L in cDC2s, thereby inducing cDC2-mediated Th2 allergic disorder [162,163].

\subsection{Atopic Dermatitis (AD)}

$\mathrm{AD}$, also known as eczema, is one of the most common forms of skin ailments. It is characterized by IgE-mediated hypersensitivity to environmental or food allergens and by dry and inflamed skin in humans [164]. In patients with AD, epidermal DCs carry FceRI on their surfaces, which is the high-affinity receptor for IgE [165-167]. AD is characterized by the presence of two major cell types, Langerhans cells (LCs) and inflammatory epidermal DCs. Both of the cell types highly express the FceRI receptor in humans [168]. LCs normally reside in the skin, but iDCs localize only where inflammation occurs. These cells take up the allergen and present it to either Th1 or Th2 cells depending on the cell types. Human LCs present to Th2 cells while iDCs present to Th1 cells $[169,170]$.

\subsection{Allergic Rhinitis (AR)}

Also known as hay fever, AR is a nasal inflammation that occurs when the body is exposed to an airborne allergen. It manifests as nasal discharge, sneezing, and ocular discharge with redness and swelling of the eyes in human [171]. In AR, Th2 cytokines are induced in CD4 ${ }^{+} \mathrm{T}$ cells by mDCs (myeloid DCs) expressing lower levels of the ICOS ligand, which is a costimulatory molecule important for DC-T-cell crosstalk. Although ICOS is linked to Th1 responses, its expression is significantly reduced in patients with allergic rhinitis [172], whereas OX40L expression is significantly increased and has a sentinel role in promoting Th2 polarization of $\mathrm{CD}^{+}$naïve $\mathrm{T}$ cells within the $\mathrm{LNs}$. Therefore, it has been suggested that the OX40L and TSLP may be a therapeutic target for AR patients [173-175].

\section{Treatment for Th2-Polarized Immune Disorder}

Parasitic infections or allergen invasion stimulate Th2 immunity by expressing Th2 associated cytokines. However, prolonged secretion of Th2 cytokines occasionally leads to adverse allergic reactions in humans, characterized by high serum levels of IgE in allergic disorders, such as AD, asthma, rhinitis, and hay fevers. Thus, the secretion of Th2 cytokines needs to be tightly controlled. Although a detailed therapeutic mechanism is beyond the scope of this review, we briefly discuss the current therapeutic approaches, which are focused on the Th1/Th2 immune balancing from Th2 skewing immunity. The idea behind developing and designing any drug is mainly based on three approaches: First, by blocking the key factor required for secretion of Th2 cytokines; second, by targeting the important signals required for differentiation and survival of Th2 immune cells; and third, by activating Th1 immunity to restore the Th1/Th2 immune balance. For example, eosinophils, a well-known myeloid lineage, rapidly infiltrate into the regions of inhaled allergens or parasitic infections, leading to the conscription of other immune cells, such as DCs, mast cells, basophils, and NKT cells, to enforce Th2 responses. Targeting these intermediate pathways could be the best approach to designing Th2 drugs. In this section, we reviewed the current therapeutic approaches for the treatment of Th2 immune disorders in the aspect of pharmacology, biologics, and molecular targets [176] (Table 2). 
Table 2. Approaches for treatment of Th2-mediated immune disorders.

\begin{tabular}{|c|c|c|c|}
\hline Drug & Target & Disorder & References \\
\hline \multicolumn{4}{|c|}{ Pharmacological (Inhibitors) } \\
\hline CsA \& FK506 & NFAT, AP1 & $\mathrm{AD}$ & {$[137,138]$} \\
\hline Vitamin E & $\mathrm{NF}-\kappa \mathrm{B}, \mathrm{AP} 1$ & $\mathrm{AD}$ & {$[177,178]$} \\
\hline Parthenolide & IL-4 & Allergy & {$[179,180]$} \\
\hline Aspirin & STAT6 & Allergy, AS & [181] \\
\hline \multicolumn{4}{|c|}{ Biologics (IL-4, 5, 13 directed therapies) } \\
\hline Omalizumab & Anti-IgE & $\mathrm{AD}, \mathrm{AS}, \mathrm{AR}, \mathrm{CSU}, \mathrm{EE}$ & [182-186] \\
\hline Dupilumab & Anti-IL-4/IL-13 & $\mathrm{AD}, \mathrm{AS}, \mathrm{NP}$ & {$[187,188]$} \\
\hline Lebrikizumab & Anti-IL-4/IL-13 & $\mathrm{AD}$ & [189-191] \\
\hline Tralokinumab & Anti-IL-13 & $\mathrm{AD}$ & {$[192,193]$} \\
\hline Pascolizumab & Anti-IL-4 & AS & [194] \\
\hline Pitrakinra & Anti-IL-4/IL-13 & $\mathrm{AD}, \mathrm{AS}$ & [195] \\
\hline Mepolizumab & Anti-IL-5 & $\mathrm{AD}$ & [196-199] \\
\hline Reslizumab & Anti-IL-5 & AS & [200] \\
\hline Benralizumab & Anti-IL-5 & AS & [201] \\
\hline Anrukinzumab & Anti-IL-13 & AS, ulcerative colitis & [202] \\
\hline Ligelizumab & Anti-IgE & $\mathrm{AD}, \mathrm{AS}$ & [203] \\
\hline Nemolizumab & Anti-IL-31 & $\mathrm{AD}$ & [204] \\
\hline Ustekinumab & Anti-IL-12/23 & Psoriasis, AD & {$[205,206]$} \\
\hline Fezakinumab & Anti-IL-22 & $\mathrm{AD}$ & [207] \\
\hline \multicolumn{4}{|c|}{ TSLP directed therapy } \\
\hline Tezepelumab & Anti-TSLP & $\mathrm{AD}$ & [207] \\
\hline \multicolumn{4}{|c|}{ Molecular Targets (microRNA) } \\
\hline miR-155 & $\begin{array}{l}\text { c-Maf (IL-4 } \\
\text { promoter) }\end{array}$ & AD, Allergy & {$[208,209]$} \\
\hline miR-126 & Repress IL-4, 5, 13 & Allergy & [210] \\
\hline $\operatorname{miR}-133 b$ & Nlrp3 & AR & [211] \\
\hline miR-135a & GATA3 & $\mathrm{AR}$ & [212] \\
\hline miR-106b & Egr2 & Allergy & [213] \\
\hline miR-138,371,544,145,214 & Runx3 & AS & [214] \\
\hline
\end{tabular}

\subsection{Pharmacological}

Tacrolimus (FK506) and Cyclosporine-A are the well-known immunosuppressive drugs, which have been used successfully in the treatment of $\mathrm{AD}$, and organ transplantation to prevent graft-versus-host diseases by targeting NFAT and AP1 proteins, leading to inhibition of calcineurin and IL-4 production in both humans and treated animals $[215,216]$. Parthenolide acts as an anti-inflammatory drug used for the treatment of allergic disease by suppressing IL-4 in both humans and mice $[179,180]$. Aspirin has been successfully used in the treatment of allergic diseases, like childhood asthma, which inhibits STAT6 activation via the IL-4 and IL-13 signaling pathway [181]. Vitamin E has been used for the treatment of $\mathrm{AD}$ patients because it is a potent antioxidant, with the ability to decrease the serum IgE level by blocking IL-4 secretion through interfering with the NF- $\mathrm{KB}$ and AP1 binding to P1 and PRE-I/P4 sites on the IL-4 promoter in both mouse and human cells $[177,178]$.

\subsection{Biological (Anti-Interleukins)}

Several anti-interleukins are being used successfully in the treatment of Th2 mediated immune disorders (Table 1). In addition to biologics, genetically engineered DCs expressing IL-4 have been shown in controlling arthritis in a mouse collagen-induced arthritis model [217]. Mouse DCs especially myeloid DCs and epidermal LCs expressing CCL17 and CCL22, a chemoattractant of Th2 cells, have been reported to have capacity in controlling AD by blocking the IL-4/STAT-6 signaling pathway [218]. The details of the DC-mediated vaccination and immunotherapeutic approach in both humans and mice for Th2 skewing allergic disorders are well described in the following references [176,219-225]. 


\subsection{Molecular (microRNA)}

MicroRNAs are recently counted on the list of treatment categories for Th2-mediated immune disorders, which are summarized briefly in Table 1. It was reported that miR-135a controls AR by regulating Th1/Th2 immune balancing in the murine model [212]. MicroRNA-155 regulates various steps of DC-associated Th2 responses by targeting PU.1 transcription factor in controlling allergic airway inflammation in mice [209]. Additionally, miR-155 and miR-146a regulate 'S1pr1' a bioactive lipid compound in controlling inflammation [208]. MiR-106b has been shown in controlling allergic inflammation by negatively regulating BMDC-mediated Th2 polarization in mice through targeting early growth response gene-2 'Egr2' [213]. Qui et al. (2017) have shown that miR-371, miR-138, miR-544, miR-145, and miR-214 can modulate the Th1/Th2 balance in a mouse asthma model through the combinatorial regulation of Runx3 [214].

\subsection{Hygiene Hypothesis}

In addition to biological and pharmacological treatment, hygiene hypothesis theory recently gained more attention towards preventing allergic disease [226-229]. Bart et al. (2017) described that the ECs as an outer barrier are constantly influenced by environmental factors. The danger signals and metabolites derived from the microbiome also trigger the immune response and thus it is important to rheostats immunoregulation. Thus, preventing strategies could be implemented to control the allergenic responses. Parasitic infection especially helminth has also been shown to control human allergic disease and autoimmune disorders [230].

\section{Conclusions and Future Directions}

As professional antigen presenting cells, DCs play a major role in controlling and maintaining the immune homeostasis in the body by means of antigen recognition and presentation to the naïve $\mathrm{T}$ cells to induce specific immune responses against harmful antigens. This review described the current understandings of the Th2 immunity induced by specific DC subsets, especially the CDC2s, and their roles in determining the specific pathways that drive and determine the Th1 versus Th2 immune responses. Th2-specific antigens or allergens readily recognized and presented by DCs eventually lead to the induction of the Th2 immune responses, resulting in the clearance of the antigen or may cause Th2-skewing chronic inflammatory disorders. In this review, we have discussed the DC-mediated Th2 polarization in connection with intrinsic, i.e., genetic factors, such as certain gene-related mutations or certain DC-specific genetic aberrations, and extrinsic, i.e., environmental factors, such as allergens, PAMPs, DAMPs, TLRs etc. The genetic factors required for the cDC2 development are essential for the induction of the DC-mediated Th2 immunity while specific environmental factors, such as the allergens or the extracellular parasites, that drive DCs to elicit Th2 polarization in the body. The detailed mechanisms underlying the induction of DC-mediated Th2 immunity to each antigen remain to be further elucidated, which will provide a better understanding of the DC-mediated Th2 immunity, eventually making progress in the field of drug development and therapeutic interventions for Th2-biased chronic inflammatory disorders.

Author Contributions: The review was designed and finalized by Y.-S.B., drafted by S.K. and M.U.A., Y.J. All the authors contributed to this review through the literature search, writing, and providing input to the respective subsections. All authors approved the final version.

Funding: This work was supported by a National Research Foundation (NRF) grant funded by the Korea Ministry of Science and ICT (SRC-2017R1A5A1014560) and in part by a grant of the Korea Health Technology R\&D Project through the Korea Health Industry Development Institute (KHIDI) funded by the Ministry of Health \& Welfare, Republic of Korea (HI16C1074). This work was also supported in part by the grant of Individual Basic Science and Engineering Research Program (2018R1D1A1B07048567) funded by the Korean National Research Foundation.

Conflicts of Interest: The authors have no conflicts of interest to declare. The funders had no role in the design of the study or in the writing of the manuscript. 


\section{Abbreviations}

\begin{tabular}{|c|c|}
\hline $\mathrm{AD}$ & atopic dermatitis \\
\hline APCs & antigen presenting cells \\
\hline AR & allergic rhinitis \\
\hline AS & asthma \\
\hline BMDCs & bone marrow-derived DCs \\
\hline cDCs & conventional/classical dendritic cells \\
\hline CSU & chronic spontaneous urticarial \\
\hline CIA & collagen-induced arthritis \\
\hline CLRs & c-type lectin receptors \\
\hline CRn & chronic rhinosinusitis \\
\hline CXCL13 & chemokine receptor CXCR5 \\
\hline DAMP & damage associated molecular pattern \\
\hline $\mathrm{DCs}$ & dendritic cells \\
\hline DC-SIGN & $\begin{array}{l}\text { dendritic cell-specific intercellular adhesion molecule } \\
\text { 3-grabbing nonintegrin }\end{array}$ \\
\hline DTR & diphtheria toxin receptor \\
\hline EE & eosinophilic esophagitis \\
\hline ECs & epithelial cells \\
\hline EMP & early myeloid progenitors \\
\hline ER & endoplasmic reticulum \\
\hline HDM & house dust mite \\
\hline $\mathrm{Hu}-\mathrm{mAb}$ & humanized monoclonal antibody \\
\hline HSC & hematopoietic stem cells \\
\hline IDO & indoleamine 2, 3 - dioxygenase \\
\hline IL & interleukin \\
\hline ILCs & innate lymphoid cells \\
\hline IFN- $\gamma$ & interferon-gamma \\
\hline IPF & idiopathic pulmonary fibrosis \\
\hline IRF4 & interferon regulatory factor \\
\hline KHIDI & Korea health industry development institute \\
\hline Klf4 & kruppel-like factor 4 \\
\hline $\operatorname{Lf} \alpha$ & lymphotoxin $\alpha$ \\
\hline $\mathrm{MC}$ & mast cell \\
\hline MHC & major histocompatablility complex \\
\hline $\operatorname{miR}$ & microRNA \\
\hline MM & macrophage mannose receptor \\
\hline Mo-DCs & monocyte derived dendritic cells \\
\hline MyD88 & myeloid differentiation primary response 88 \\
\hline Mib-1 & mind-bomb-1 \\
\hline MIIC & MHC II-containing Compartment \\
\hline NF-kB & nuclear factor kappa B \\
\hline NKT & natural killer T cells \\
\hline NLRP3 & NLR family pyrin domain containing 3 \\
\hline $\mathrm{NP}$ & nasal polyposis \\
\hline NRF & national research foundation \\
\hline PAMP & pathogen-associated molecular pattern \\
\hline PAR 1-3 & protease activated receptors \\
\hline $\mathrm{pDC}$ & plasmacytoid dendritic cells \\
\hline $\mathrm{PE}$ & peripheral eosinophilia \\
\hline PRRs & pattern recognition receptors \\
\hline P2R & purinergic type 2 receptor \\
\hline Sharpin & SHANK-associated RH domain-interacting protein \\
\hline
\end{tabular}




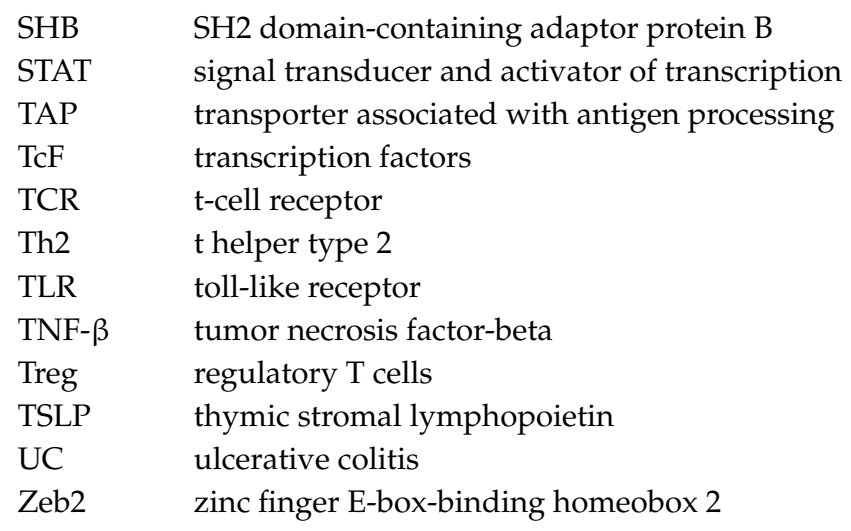

\section{References}

1. Steinman, R.M.; Cohn, Z.A. Identification of a novel cell type in peripheral lymphoid organs of mice. I. Morphology, quantitation, tissue distribution. J. Exp. Med. 1973, 137, 1142-1162. [CrossRef] [PubMed]

2. Steinman, R.M. Decisions about dendritic cells: Past, present, and future. Annu. Rev. Immunol. 2012, 30, 1-22. [CrossRef] [PubMed]

3. Na, H.; Cho, M.; Chung, Y. Regulation of Th2 Cell Immunity by Dendritic Cells. Immune Netw. 2016, 16, 1-12. [CrossRef] [PubMed]

4. MacDonald, A.S.; Maizels, R.M. Alarming dendritic cells for Th2 induction. J. Exp. Med. 2008, 205, 13-17. [CrossRef]

5. Kim, B.; Kim, T.H. Fundamental role of dendritic cells in inducing Th2 responses. Kor. J. Intern. Med. 2018, 33, 483-489. [CrossRef] [PubMed]

6. Sitcharungsi, R.; Sirivichayakul, C. Allergic diseases and helminth infections. Pathog. Glob. Health 2013, 107, 110-115. [CrossRef] [PubMed]

7. Bakiri, A.H.; Mingomataj, E.C. Parasites induced skin allergy: A strategic manipulation of the host immunity. J. Clin. Med. Res. 2010, 2, 247-255. [CrossRef] [PubMed]

8. Lynch, N.R.; Goldblatt, J.; Le Souef, P.N. Parasite infections and the risk of asthma and atopy. Thorax 1999, 54, 659-660. [CrossRef] [PubMed]

9. Joffre, O.P.; Segura, E.; Savina, A.; Amigorena, S. Cross-presentation by dendritic cells. Nat. Rev. Immunol. 2012, 12, 557-569. [CrossRef] [PubMed]

10. Paul, W.E.; Zhu, J. How are T(H)2-type immune responses initiated and amplified? Nat. Rev. Immunol. 2010, 10, 225-235. [CrossRef]

11. Walker, J.A.; McKenzie, A.N.J. TH2 cell development and function. Nat. Rev. Immunol. 2018, 18, 121-133. [CrossRef] [PubMed]

12. Maier, E.; Duschl, A.; Horejs-Hoeck, J. STAT6-dependent and -independent mechanisms in Th2 polarization. Eur. J. Immunol. 2012, 42, 2827-2833. [CrossRef] [PubMed]

13. Gao, Y.; Nish, S.A.; Jiang, R.; Hou, L.; Licona-Limon, P.; Weinstein, J.S.; Zhao, H.; Medzhitov, R. Control of T helper 2 responses by transcription factor IRF4-dependent dendritic cells. Immunity 2013, 39, 722-732. [CrossRef] [PubMed]

14. Tussiwand, R.; Everts, B.; Grajales-Reyes, G.E.; Kretzer, N.M.; Iwata, A.; Bagaitkar, J.; Wu, X.; Wong, R.; Anderson, D.A.; Murphy, T.L.; et al. Klf4 expression in conventional dendritic cells is required for T helper 2 cell responses. Immunity 2015, 42, 916-928. [CrossRef]

15. Ahmed, M.S.; Kang, M.H.; Lee, E.; Park, Y.; Jeong, Y.; Bae, Y.S. SH2 domain-containing adaptor protein B expressed in dendritic cells is involved in T-cell homeostasis by regulating dendritic cell-mediated Th2 immunity. Clin. Exp. Vaccine Res. 2017, 6, 50-60. [CrossRef]

16. Kapsenberg, M.L. Dendritic-cell control of pathogen-driven T-cell polarization. Nat. Rev. Immunol. 2003, 3, 984-993. [CrossRef] [PubMed]

17. Murakami, R.; Denda-Nagai, K.; Hashimoto, S.; Nagai, S.; Hattori, M.; Irimura, T. A unique dermal dendritic cell subset that skews the immune response toward Th2. PLoS ONE 2013, 8, e73270. [CrossRef] 
18. Kaplan, M.H.; Hufford, M.M.; Olson, M.R. The development and in vivo function of T helper 9 cells. Nat. Rev. Immunol. 2015, 15, 295-307. [CrossRef]

19. Zambrano-Zaragoza, J.F.; Romo-Martinez, E.J.; Duran-Avelar Mde, J.; Garcia-Magallanes, N.; Vibanco-Perez, N. Th17 cells in autoimmune and infectious diseases. Int. J. Inflamm. 2014, 2014, 651503. [CrossRef]

20. Weaver, C.T.; Elson, C.O.; Fouser, L.A.; Kolls, J.K. The Th17 pathway and inflammatory diseases of the intestines, lungs, and skin. Annu. Rev. Pathol. 2013, 8, 477-512. [CrossRef] [PubMed]

21. Sakaguchi, S.; Yamaguchi, T.; Nomura, T.; Ono, M. Regulatory T cells and immune tolerance. Cell 2008, 133, 775-787. [CrossRef] [PubMed]

22. Bettelli, E.; Carrier, Y.; Gao, W.; Korn, T.; Strom, T.B.; Oukka, M.; Weiner, H.L.; Kuchroo, V.K. Reciprocal developmental pathways for the generation of pathogenic effector TH17 and regulatory T cells. Nature 2006, 441, 235-238. [CrossRef]

23. Ansel, K.M.; Djuretic, I.; Tanasa, B.; Rao, A. Regulation of Th2 differentiation and Il4 locus accessibility. Annu Rev. Immunol. 2006, 24, 607-656. [CrossRef]

24. Min, B.; Prout, M.; Hu-Li, J.; Zhu, J.; Jankovic, D.; Morgan, E.S.; Urban, J.F., Jr.; Dvorak, A.M.; Finkelman, F.D.; LeGros, G.; et al. Basophils produce IL-4 and accumulate in tissues after infection with a Th2-inducing parasite. J. Exp. Med. 2004, 200, 507-517. [CrossRef]

25. Perrigoue, J.G.; Saenz, S.A.; Siracusa, M.C.; Allenspach, E.J.; Taylor, B.C.; Giacomin, P.R.; Nair, M.G.; Du, Y.; Zaph, C.; van Rooijen, N.; et al. MHC class II-dependent basophil-CD4+ T cell interactions promote T(H)2 cytokine-dependent immunity. Nat. Immunol. 2009, 10, 697-705. [CrossRef] [PubMed]

26. Gregory, G.D.; Raju, S.S.; Winandy, S.; Brown, M.A. Mast cell IL-4 expression is regulated by Ikaros and influences encephalitogenic Th1 responses in EAE. J. Clin. Investig. 2006, 116, 1327-1336. [CrossRef] [PubMed]

27. Ierna, M.X.; Scales, H.E.; Saunders, K.L.; Lawrence, C.E. Mast cell production of IL-4 and TNF may be required for protective and pathological responses in gastrointestinal helminth infection. Mucosal Immunol. 2008, 1, 147-155. [CrossRef] [PubMed]

28. Yoshimoto, T.; Paul, W.E. CD4pos, NK1.1pos T cells promptly produce interleukin 4 in response to in vivo challenge with anti-CD3. J. Exp. Med. 1994, 179, 1285-1295. [CrossRef] [PubMed]

29. Zheng, W.; Flavell, R.A. The transcription factor GATA-3 is necessary and sufficient for Th2 cytokine gene expression in CD4 T cells. Cell 1997, 89, 587-596. [CrossRef]

30. Scheinman, E.J.; Avni, O. Transcriptional regulation of GATA3 in T helper cells by the integrated activities of transcription factors downstream of the interleukin-4 receptor and T cell receptor. J. Biol. Chem. 2009, 284, 3037-3048. [CrossRef]

31. O'Garra, A.; Gabrysova, L. Transcription Factors Directing Th2 Differentiation: Gata-3 Plays a Dominant Role. J. Immunol. 2016, 196, 4423-4425. [CrossRef] [PubMed]

32. Nakanishi, K. Basophils are potent antigen-presenting cells that selectively induce Th2 cells. Eur. J. Immunol. 2010, 40, 1836-1842. [CrossRef] [PubMed]

33. Nakanishi, K. Basophils as APC in Th2 response in allergic inflammation and parasite infection. Curr. Opin. Immunol. 2010, 22, 814-820. [CrossRef] [PubMed]

34. Sokol, C.L.; Chu, N.Q.; Yu, S.; Nish, S.A.; Laufer, T.M.; Medzhitov, R. Basophils function as antigen-presenting cells for an allergen-induced T helper type 2 response. Nat. Immunol. 2009, 10, 713-720. [CrossRef] [PubMed]

35. Pulendran, B.; Tang, H.; Manicassamy, S. Programming dendritic cells to induce T(H)2 and tolerogenic responses. Nat. Immunol. 2010, 11, 647-655. [CrossRef] [PubMed]

36. Tang, H.; Cao, W.; Kasturi, S.P.; Ravindran, R.; Nakaya, H.I.; Kundu, K.; Murthy, N.; Kepler, T.B.; Malissen, B.; Pulendran, $\mathrm{B}$. The $\mathrm{T}$ helper type 2 response to cysteine proteases requires dendritic cell-basophil cooperation via ROS-mediated signaling. Nat. Immunol. 2010, 11, 608-617. [CrossRef]

37. Woo, Y.; Jeong, D.; Chung, D.H.; Kim, H.Y. The roles of innate lymphoid cells in the development of asthma. Immune Netw. 2014, 14, 171-181. [CrossRef]

38. Pelly, V.S.; Kannan, Y.; Coomes, S.M.; Entwistle, L.J.; Ruckerl, D.; Seddon, B.; MacDonald, A.S.; McKenzie, A.; Wilson, M.S. IL-4-producing ILC2s are required for the differentiation of TH2 cells following Heligmosomoides polygyrus infection. Mucosal Immunol. 2016, 9, 1407-1417. [CrossRef] 
39. Kim, B.S.; Siracusa, M.C.; Saenz, S.A.; Noti, M.; Monticelli, L.A.; Sonnenberg, G.F.; Hepworth, M.R.; Van Voorhees, A.S.; Comeau, M.R.; Artis, D. TSLP elicits IL-33-independent innate lymphoid cell responses to promote skin inflammation. Sci. Transl. Med. 2013, 5, 170ra16. [CrossRef]

40. Rimoldi, M.; Chieppa, M.; Salucci, V.; Avogadri, F.; Sonzogni, A.; Sampietro, G.M.; Nespoli, A.; Viale, G.; Allavena, P.; Rescigno, M. Corrigendum: Intestinal immune homeostasis is regulated by the crosstalk between epithelial cells and dendritic cells. Nat. Immunol. 2015, 16, 326. [CrossRef]

41. He, R.; Oyoshi, M.K.; Garibyan, L.; Kumar, L.; Ziegler, S.F.; Geha, R.S. TSLP acts on infiltrating effector T cells to drive allergic skin inflammation. Proc. Natl. Acad. Sci. USA 2008, 105, 11875-11880. [CrossRef]

42. Kool, M.; Soullie, T.; van Nimwegen, M.; Willart, M.A.; Muskens, F.; Jung, S.; Hoogsteden, H.C.; Hammad, H.; Lambrecht, B.N. Alum adjuvant boosts adaptive immunity by inducing uric acid and activating inflammatory dendritic cells. J. Exp. Med. 2008, 205, 869-882. [CrossRef]

43. Yang, D.; Postnikov, Y.V.; Li, Y.; Tewary, P.; de la Rosa, G.; Wei, F.; Klinman, D.; Gioannini, T.; Weiss, J.P.; Furusawa, T.; et al. High-mobility group nucleosome-binding protein 1 acts as an alarmin and is critical for lipopolysaccharide-induced immune responses. J. Exp. Med. 2012, 209, 157-171. [CrossRef]

44. Mjosberg, J.; Spits, H. Type 2 innate lymphoid cells-new members of the "type 2 franchise" that mediate allergic airway inflammation. Eur. J. Immunol. 2012, 42, 1093-1096. [CrossRef]

45. Zhou, B.; Comeau, M.R.; De Smedt, T.; Liggitt, H.D.; Dahl, M.E.; Lewis, D.B.; Gyarmati, D.; Aye, T.; Campbell, D.J.; Ziegler, S.F. Thymic stromal lymphopoietin as a key initiator of allergic airway inflammation in mice. Nat. Immunol. 2005, 6, 1047-1053. [CrossRef]

46. Saenz, S.A.; Taylor, B.C.; Artis, D. Welcome to the neighborhood: Epithelial cell-derived cytokines license innate and adaptive immune responses at mucosal sites. Immunol. Rev. 2008, 226, 172-190. [CrossRef]

47. Wang, Y.H.; Angkasekwinai, P.; Lu, N.; Voo, K.S.; Arima, K.; Hanabuchi, S.; Hippe, A.; Corrigan, C.J.; Dong, C.; Homey, B.; et al. IL-25 augments type 2 immune responses by enhancing the expansion and functions of TSLP-DC-activated Th2 memory cells. J. Exp. Med. 2007, 204, 1837-1847. [CrossRef]

48. Hongiia, L.; Caiqing, Z.; Degan, L.; Fen, L.; Chao, W.; Jinxiang, W.; Liang, D. IL-25 promotes Th2 immunity responses in airway inflammation of asthmatic mice via activation of dendritic cells. Inflammation 2014, 37 , 1070-1077. [CrossRef]

49. Angkasekwinai, P.; Park, H.; Wang, Y.H.; Chang, S.H.; Corry, D.B.; Liu, Y.J.; Zhu, Z.; Dong, C. Interleukin 25 promotes the initiation of proallergic type 2 responses. J. Exp. Med. 2007, 204, 1509-1517. [CrossRef]

50. Caruso, R.; Sarra, M.; Stolfi, C.; Rizzo, A.; Fina, D.; Fantini, M.C.; Pallone, F.; MacDonald, T.T.; Monteleone, G. Interleukin-25 inhibits interleukin-12 production and Th1 cell-driven inflammation in the gut. Gastroenterology 2009, 136, 2270-2279. [CrossRef]

51. Kleinschek, M.A.; Owyang, A.M.; Joyce-Shaikh, B.; Langrish, C.L.; Chen, Y.; Gorman, D.M.; Blumenschein, W.M.; McClanahan, T.; Brombacher, F.; Hurst, S.D.; et al. IL-25 regulates Th17 function in autoimmune inflammation. J. Exp. Med. 2007, 204, 161-170. [CrossRef]

52. Ballantyne, S.J.; Barlow, J.L.; Jolin, H.E.; Nath, P.; Williams, A.S.; Chung, K.F.; Sturton, G.; Wong, S.H.; McKenzie, A.N. Blocking IL-25 prevents airway hyperresponsiveness in allergic asthma. J. Allergy Clin. Immunol. 2007, 120, 1324-1331. [CrossRef]

53. Schmitz, J.; Owyang, A.; Oldham, E.; Song, Y.; Murphy, E.; McClanahan, T.K.; Zurawski, G.; Moshrefi, M.; Qin, J.; Li, X.; et al. IL-33, an interleukin-1-like cytokine that signals via the IL-1 receptor-related protein ST2 and induces T helper type 2-associated cytokines. Immunity 2005, 23, 479-490. [CrossRef]

54. Besnard, A.G.; Togbe, D.; Guillou, N.; Erard, F.; Quesniaux, V.; Ryffel, B. IL-33-activated dendritic cells are critical for allergic airway inflammation. Eur. J. Immunol. 2011, 41, 1675-1686. [CrossRef]

55. Eiwegger, T.; Akdis, C.A. IL-33 links tissue cells, dendritic cells and Th2 cell development in a mouse model of asthma. Eur. J. Immunol. 2011, 41, 1535-1538. [CrossRef]

56. Humphreys, N.E.; Xu, D.; Hepworth, M.R.; Liew, F.Y.; Grencis, R.K. IL-33, a potent inducer of adaptive immunity to intestinal nematodes. J. Immunol. 2008, 180, 2443-2449. [CrossRef]

57. Abraham, S.N.; St John, A.L. Mast cell-orchestrated immunity to pathogens. Nat. Rev. Immunol. 2010, 10, 440-452. [CrossRef]

58. Lloyd, C.M. IL-33 family members and asthma-Bridging innate and adaptive immune responses. Curr. Opin. Immunol. 2010, 22, 800-806. [CrossRef]

59. Kumamoto, Y.; Linehan, M.; Weinstein, J.S.; Laidlaw, B.J.; Craft, J.E.; Iwasaki, A. CD301b(+) dermal dendritic cells drive T helper 2 cell-mediated immunity. Immunity 2013, 39, 733-743. [CrossRef] 
60. Lewkowich, I.P.; Lajoie, S.; Stoffers, S.L.; Suzuki, Y.; Richgels, P.K.; Dienger, K.; Sproles, A.A.; Yagita, H.; Hamid, Q.; Wills-Karp, M. PD-L2 modulates asthma severity by directly decreasing dendritic cell IL-12 production. Mucosal Immunol. 2013, 6, 728-739. [CrossRef]

61. Kitajima, M.; Ziegler, S.F. Cutting edge: Identification of the thymic stromal lymphopoietin-responsive dendritic cell subset critical for initiation of type 2 contact hypersensitivity. J. Immunol. 2013, 191, 4903-4907. [CrossRef]

62. Mayer, J.U.; Demiri, M.; Agace, W.W.; MacDonald, A.S.; Svensson-Frej, M.; Milling, S.W. Different populations of $\mathrm{CD} 11 \mathrm{~b}(+)$ dendritic cells drive Th2 responses in the small intestine and colon. Nat. Commun. 2017, 8, 15820. [CrossRef]

63. Leon, B.; Ballesteros-Tato, A.; Browning, J.L.; Dunn, R.; Randall, T.D.; Lund, F.E. Regulation of T(H)2 development by CXCR5+ dendritic cells and lymphotoxin-expressing B cells. Nat. Immunol. 2012, 13, 681-690. [CrossRef]

64. Johnson, S.; Zhan, Y.; Sutherland, R.M.; Mount, A.M.; Bedoui, S.; Brady, J.L.; Carrington, E.M.; Brown, L.E.; Belz, G.T.; Heath, W.R.; et al. Selected Toll-like receptor ligands and viruses promote helper-independent cytotoxic T cell priming by upregulating CD40L on dendritic cells. Immunity 2009, 30, 218-227. [CrossRef]

65. Vanderlocht, J.; Van Elssen, C.H.; Senden-Gijsbers, B.L.; Meek, B.; Cloosen, S.; Libon, C.; Bos, G.M.; Germeraad, W.T. Increased tumor-specific CD8+ T cell induction by dendritic cells matured with a clinical grade TLR-agonist in combination with IFN-gamma. Int. J. Immunopathol. Pharmacol. 2010, 23, 35-50. [CrossRef]

66. Nakano, H.; Free, M.E.; Whitehead, G.S.; Maruoka, S.; Wilson, R.H.; Nakano, K.; Cook, D.N. Pulmonary CD103(+) dendritic cells prime Th2 responses to inhaled allergens. Mucosal Immunol. 2012, 5, 53-65. [CrossRef]

67. Van der Borght, K.; Scott, C.L.; Martens, L.; Sichien, D.; Van Isterdael, G.; Nindl, V.; Saeys, Y.; Boon, L.; Ludewig, B.; Gillebert, T.C.; et al. Myocarditis Elicits Dendritic Cell and Monocyte Infiltration in the Heart and Self-Antigen Presentation by Conventional Type 2 Dendritic Cells. Front. Immunol. 2018, 9, 2714. [CrossRef]

68. Nutman, T.B. Looking beyond the induction of Th2 responses to explain immunomodulation by helminths. Parasite Immunol. 2015, 37, 304-313. [CrossRef]

69. Anthony, R.M.; Rutitzky, L.I.; Urban, J.F., Jr.; Stadecker, M.J.; Gause, W.C. Protective immune mechanisms in helminth infection. Nat. Rev. Immunol. 2007, 7, 975-987. [CrossRef]

70. Bigley, V.; Barge, D.; Collin, M. Dendritic cell analysis in primary immunodeficiency. Curr. Opin. Allergy Clin. Immunol. 2016, 16, 530-540. [CrossRef]

71. Willart, M.A.; Hammad, H. Alarming dendritic cells for allergic sensitization. Allergol. Int. 2010, 59, 95-103. [CrossRef] [PubMed]

72. Oppenheim, J.J.; Yang, D.; Biragyn, A.; Howard, O.M.; Plotz, P. Chemokine receptors on dendritic cells promote autoimmune reactions. Arthritis Res. 2002, 4, S183-S188. [CrossRef]

73. Sokol, C.L.; Luster, A.D. The chemokine system in innate immunity. Cold Spring Harb. Perspect. Biol. $2015,7$. [CrossRef] [PubMed]

74. Rochman, Y.; Dienger-Stambaugh, K.; Richgels, P.K.; Lewkowich, I.P.; Kartashov, A.V.; Barski, A.; Khurana Hershey, G.K.; Leonard, W.J.; Singh, H. TSLP signaling in CD4(+) T cells programs a pathogenic T helper 2 cell state. Sci. Signal 2018, 11, 521. [CrossRef] [PubMed]

75. Lo Kuan, E.; Ziegler, S.F. Thymic stromal lymphopoietin and cancer. J. Immunol. 2014, 193, 4283-4288. [CrossRef] [PubMed]

76. Wassink, L.; Vieira, P.L.; Smits, H.H.; Kingsbury, G.A.; Coyle, A.J.; Kapsenberg, M.L.; Wierenga, E.A. ICOS expression by activated human Th cells is enhanced by IL-12 and IL-23: Increased ICOS expression enhances the effector function of both Th1 and Th2 cells. J. Immunol. 2004, 173, 1779-1786. [CrossRef] [PubMed]

77. Tang, C.; Yamada, H.; Shibata, K.; Muta, H.; Wajjwalku, W.; Podack, E.R.; Yoshikai, Y. A novel role of CD30L/CD30 signaling by T-T cell interaction in Th1 response against mycobacterial infection. J. Immunol. 2008, 181, 6316-6327. [CrossRef] [PubMed]

78. Zhang, X.; Liu, Q.; Wang, J.; Li, G.; Weiland, M.; Yu, F.S.; Mi, Q.S.; Gu, J.; Zhou, L. TIM-4 is differentially expressed in the distinct subsets of dendritic cells in skin and skin-draining lymph nodes and controls skin Langerhans cell homeostasis. Oncotarget 2016, 7, 37498-37512. [CrossRef] 
79. Abdoli, R.; Najafian, N. T Helper Cells Fate Mapping by Co-stimulatory Molecules and its Functions in Allograft Rejection and Tolerance. Int. J. Organ Transpl. Med. 2014, 5, 97-110.

80. Van Vliet, S.J.; Garcia-Vallejo, J.J.; van Kooyk, Y. Dendritic cells and C-type lectin receptors: Coupling innate to adaptive immune responses. Immunol. Cell Biol. 2008, 86, 580-587. [CrossRef]

81. Ryan, E.J.; Marshall, A.J.; Magaletti, D.; Floyd, H.; Draves, K.E.; Olson, N.E.; Clark, E.A. Dendritic cell-associated lectin-1: A novel dendritic cell-associated, C-type lectin-like molecule enhances $\mathrm{T}$ cell secretion of IL-4. J. Immunol. 2002, 169, 5638-5648. [CrossRef] [PubMed]

82. Szabo, A.; Rajnavolgyi, E. Collaboration of Toll-like and RIG-I-like receptors in human dendritic cells: tRIGgering antiviral innate immune responses. Am. J. Clin Exp. Immunol. 2013, 2, 195-207. [PubMed]

83. Lewkowich, I.P.; Day, S.B.; Ledford, J.R.; Zhou, P.; Dienger, K.; Wills-Karp, M.; Page, K. Protease-activated receptor 2 activation of myeloid dendritic cells regulates allergic airway inflammation. Respir. Res. 2011, 12, 122. [CrossRef] [PubMed]

84. Gi, M.; Im, W.; Hong, S. Dendritic cells as danger-recognizing biosensors. Sensors 2009, 9, 6730-6751. [CrossRef] [PubMed]

85. Harizi, $\mathrm{H}$. The immunobiology of prostanoid receptor signaling in connecting innate and adaptive immunity. Biomed. Res. Int. 2013, 2013, 683405. [CrossRef] [PubMed]

86. Levite, M.; Cahalon, L.; Hershkoviz, R.; Steinman, L.; Lider, O. Neuropeptides, via specific receptors, regulate T cell adhesion to fibronectin. J. Immunol. 1998, 160, 993-1000.

87. Di Virgilio, F. Purinergic mechanism in the immune system: A signal of danger for dendritic cells. Purinergic Signal 2005, 1, 205-209. [CrossRef] [PubMed]

88. Dumitriu, I.E.; Baruah, P.; Bianchi, M.E.; Manfredi, A.A.; Rovere-Querini, P. Requirement of HMGB1 and RAGE for the maturation of human plasmacytoid dendritic cells. Eur. J. Immunol. 2005, 35, 2184-2190. [CrossRef]

89. Kuppner, M.C.; Gastpar, R.; Gelwer, S.; Nossner, E.; Ochmann, O.; Scharner, A.; Issels, R.D. The role of heat shock protein (hsp70) in dendritic cell maturation: hsp70 induces the maturation of immature dendritic cells but reduces DC differentiation from monocyte precursors. Eur. J. Immunol. 2001, 31, 1602-1609. [CrossRef]

90. Wan, T.; Zhou, X.; Chen, G.; An, H.; Chen, T.; Zhang, W.; Liu, S.; Jiang, Y.; Yang, F.; Wu, Y.; et al. Novel heat shock protein Hsp70L1 activates dendritic cells and acts as a Th1 polarizing adjuvant. Blood 2004, 103, 1747-1754. [CrossRef]

91. Bell, B.D.; Kitajima, M.; Larson, R.P.; Stoklasek, T.A.; Dang, K.; Sakamoto, K.; Wagner, K.U.; Kaplan, D.H.; Reizis, B.; Hennighausen, L.; et al. The transcription factor STAT5 is critical in dendritic cells for the development of TH2 but not TH1 responses. Nat. Immunol. 2013, 14, 364-371. [CrossRef]

92. Tormo, A.J.; Gauchat, J.F. A novel role for STAT5 in DC: Controlling the Th2-response. JAKSTAT 2013, 2, e25352. [CrossRef]

93. Sun, J.; Krawczyk, C.J.; Pearce, E.J. Suppression of Th2 cell development by Notch ligands Delta1 and Delta4. J. Immunol. 2008, 180, 1655-1661. [CrossRef]

94. Liotta, F.; Frosali, F.; Querci, V.; Mantei, A.; Fili, L.; Maggi, L.; Mazzinghi, B.; Angeli, R.; Ronconi, E.; Santarlasci, V.; et al. Human immature myeloid dendritic cells trigger a TH2-polarizing program via Jagged-1/Notch interaction. J. Allergy Clin. Immunol. 2008, 121, 1000-1005. [CrossRef]

95. Lee, C.C.; Lin, C.L.; Leu, S.J.; Lee, Y.L. Overexpression of Notch ligand Delta-like-1 by dendritic cells enhances their immunoregulatory capacity and exerts antiallergic effects on Th2-mediated allergic asthma in mice. Clin. Immunol. 2018, 187, 58-67. [CrossRef]

96. Xu, X.; Gao, X.; Zhao, X.; Liao, Y.; Ji, W.; Li, Q.; Li, J. PU.1-Silenced Dendritic Cells Induce Mixed Chimerism and Alleviate Intestinal Transplant Rejection in Rats via a Th1 to Th2 Shift. Cell Physiol. Biochem. 2016, 38, 220-228. [CrossRef]

97. Yashiro, T.; Kubo, M.; Ogawa, H.; Okumura, K.; Nishiyama, C. PU.1 Suppresses Th2 Cytokine Expression via Silencing of GATA3 Transcription in Dendritic Cells. PLoS ONE 2015, 10, e0137699. [CrossRef]

98. Scott, C.L.; Soen, B.; Martens, L.; Skrypek, N.; Saelens, W.; Taminau, J.; Blancke, G.; Van Isterdael, G.; Huylebroeck, D.; Haigh, J.; et al. The transcription factor Zeb2 regulates development of conventional and plasmacytoid DCs by repressing Id2. J. Exp. Med. 2016, 213, 897-911. [CrossRef]

99. Nair, P.M.; Starkey, M.R.; Haw, T.J.; Ruscher, R.; Liu, G.; Maradana, M.R.; Thomas, R.; O'Sullivan, B.J.; Hansbro, P.M. RelB-Deficient Dendritic Cells Promote the Development of Spontaneous Allergic Airway Inflammation. Am. J. Respir. Cell Mol. Biol. 2018, 58, 352-365. [CrossRef] 
100. Jeong, H.W.; Kim, J.H.; Kim, J.Y.; Ha, S.J.; Kong, Y.Y. Mind bomb-1 in dendritic cells is specifically required for Notch-mediated T helper type 2 differentiation. PLOS ONE 2012, 7, e36359. [CrossRef]

101. Ochi, A.; Nguyen, A.H.; Bedrosian, A.S.; Mushlin, H.M.; Zarbakhsh, S.; Barilla, R.; Zambirinis, C.P.; Fallon, N.C.; Rehman, A.; Pylayeva-Gupta, Y.; et al. MyD88 inhibition amplifies dendritic cell capacity to promote pancreatic carcinogenesis via Th2 cells. J. Exp. Med. 2012, 209, 1671-1687. [CrossRef]

102. Seymour, R.E.; Hasham, M.G.; Cox, G.A.; Shultz, L.D.; Hogenesch, H.; Roopenian, D.C.; Sundberg, J.P. Spontaneous mutations in the mouse Sharpin gene result in multiorgan inflammation, immune system dysregulation and dermatitis. Genes Immunity 2007, 8, 416-421. [CrossRef] [PubMed]

103. Wang, Z.; Sokolovska, A.; Seymour, R.; Sundberg, J.P.; Hogenesch, H. SHARPIN is essential for cytokine production, NF-KB signaling, and induction of Th1 differentiation by dendritic cells. PLoS ONE 2012, 7, e31809. [CrossRef] [PubMed]

104. Hurdayal, R.; Nieuwenhuizen, N.E.; Revaz-Breton, M.; Smith, L.; Hoving, J.C.; Parihar, S.P.; Reizis, B.; Brombacher, F. Deletion of IL-4 receptor alpha on dendritic cells renders BALB/c mice hypersusceptible to Leishmania major infection. PLoS Pathog. 2013, 9, e1003699. [CrossRef]

105. Li, R.; Zheng, X.; Popov, I.; Zhang, X.; Wang, H.; Suzuki, M.; Necochea-Campion, R.D.; French, P.W.; Chen, D.; Siu, L.; et al. Gene silencing of IL-12 in dendritic cells inhibits autoimmune arthritis. J. Transl. Med. 2012, 10, 19. [CrossRef] [PubMed]

106. Gold, M.J.; Antignano, F.; Hughes, M.R.; Zaph, C.; McNagny, K.M. Dendritic-cell expression of Ship1 regulates Th2 immunity to helminth infection in mice. Eur. J. Immunol. 2016, 46, 122-130. [CrossRef] [PubMed]

107. Webb, L.M.; Lundie, R.J.; Borger, J.G.; Brown, S.L.; Connor, L.M.; Cartwright, A.N.; Dougall, A.M.; Wilbers, R.H.; Cook, P.C.; Jackson-Jones, L.H.; et al. Type I interferon is required for T helper (Th) 2 induction by dendritic cells. EMBO J. 2017, 36, 2404-2418. [CrossRef]

108. Holmqvist, K.; Cross, M.J.; Rolny, C.; Hagerkvist, R.; Rahimi, N.; Matsumoto, T.; Claesson-Welsh, L.; Welsh, M. The adaptor protein shb binds to tyrosine 1175 in vascular endothelial growth factor (VEGF) receptor-2 and regulates VEGF-dependent cellular migration. J. Biol. Chem. 2004, 279, 22267-22275. [CrossRef]

109. Hooshmand-Rad, R.; Lu, L.; Heldin, C.H.; Claesson-Welsh, L.; Welsh, M. Platelet-derived growth factor-mediated signaling through the Shb adaptor protein: Effects on cytoskeletal organization. Exp. Cell Res. 2000, 257, 245-254. [CrossRef]

110. Welsh, M.; Songyang, Z.; Frantz, J.D.; Trub, T.; Reedquist, K.A.; Karlsson, T.; Miyazaki, M.; Cantley, L.C.; Band, H.; Shoelson, S.E. Stimulation through the T cell receptor leads to interactions between SHB and several signaling proteins. Oncogene 1998, 16, 891-901. [CrossRef]

111. Gustafsson, K.; Willebrand, E.; Welsh, M. Absence of the adaptor protein Shb potentiates the T helper type 2 response in a mouse model of atopic dermatitis. Immunology 2014, 143, 33-41. [CrossRef]

112. Fedulov, A.V.; Kobzik, L. Allergy risk is mediated by dendritic cells with congenital epigenetic changes. Am. J. Respir. Cell Mol. Biol. 2011, 44, 285-292. [CrossRef]

113. Cook, P.C.; Owen, H.; Deaton, A.M.; Borger, J.G.; Brown, S.L.; Clouaire, T.; Jones, G.R.; Jones, L.H.; Lundie, R.J.; Marley, A.K.; et al. A dominant role for the methyl-CpG-binding protein Mbd2 in controlling Th2 induction by dendritic cells. Nat. Commun. 2015, 6, 6920. [CrossRef]

114. Zech, A.; Ayata, C.K.; Pankratz, F.; Meyer, A.; Baudiss, K.; Cicko, S.; Yegutkin, G.G.; Grundmann, S.; Idzko, M. MicroRNA-155 modulates P2R signaling and Th2 priming of dendritic cells during allergic airway inflammation in mice. Allergy 2015, 70, 1121-1129. [CrossRef]

115. Boonstra, A.; Asselin-Paturel, C.; Gilliet, M.; Crain, C.; Trinchieri, G.; Liu, Y.J.; O'Garra, A. Flexibility of mouse classical and plasmacytoid-derived dendritic cells in directing $\mathrm{T}$ helper type 1 and 2 cell development: Dependency on antigen dose and differential toll-like receptor ligation. J. Exp. Med. 2003, 197, 101-109. [CrossRef]

116. Tanaka, H.; Demeure, C.E.; Rubio, M.; Delespesse, G.; Sarfati, M. Human monocyte-derived dendritic cells induce naive T cell differentiation into T helper cell type 2 (Th2) or Th1/Th2 effectors. Role of stimulator/responder ratio. J. Exp. Med. 2000, 192, 405-412. [CrossRef]

117. Lutz, M.B. How quantitative differences in dendritic cell maturation can direct TH1/TH2-cell polarization. Oncoimmunology 2013, 2, e22796. [CrossRef]

118. Barrett, N.A.; Maekawa, A.; Rahman, O.M.; Austen, K.F.; Kanaoka, Y. Dectin-2 recognition of house dust mite triggers cysteinyl leukotriene generation by dendritic cells. J. Immunol. 2009, 182, 1119-1128. [CrossRef] 
119. Lambrecht, B.N.; Hammad, H. Biology of lung dendritic cells at the origin of asthma. Immunity 2009, 31, 412-424. [CrossRef]

120. Royer, P.J.; Emara, M.; Yang, C.; Al-Ghouleh, A.; Tighe, P.; Jones, N.; Sewell, H.F.; Shakib, F.; Martinez-Pomares, L.; Ghaemmaghami, A.M. The mannose receptor mediates the uptake of diverse native allergens by dendritic cells and determines allergen-induced T cell polarization through modulation of IDO activity. J. Immunol. 2010, 185, 1522-1531. [CrossRef]

121. Chambers, S.J.; Bertelli, E.; Winterbone, M.S.; Regoli, M.; Man, A.L.; Nicoletti, C. Adoptive transfer of dendritic cells from allergic mice induces specific immunoglobulin $\mathrm{E}$ antibody in naive recipients in absence of antigen challenge without altering the T helper 1/T helper 2 balance. Immunology 2004, 112, 72-79. [CrossRef]

122. Ruiter, B.; Shreffler, W.G. The role of dendritic cells in food allergy. J. Allergy Clin. Immunol. 2012, 129, 921-928. [CrossRef]

123. Smit, J.J.; Bol-Schoenmakers, M.; Hassing, I.; Fiechter, D.; Boon, L.; Bleumink, R.; Pieters, R.H. The role of intestinal dendritic cells subsets in the establishment of food allergy. Clin. Exp. Allergy J. Br. Soc. Allergy Clin. Immunol. 2011, 41, 890-898. [CrossRef]

124. Blazquez, A.B.; Berin, M.C. Gastrointestinal dendritic cells promote Th2 skewing via OX40L. J. Immunol. 2008, 180, 4441-4450. [CrossRef]

125. Eisenbarth, S.C.; Piggott, D.A.; Bottomly, K. The master regulators of allergic inflammation: Dendritic cells in Th2 sensitization. Curr. Opin. Immunol. 2003, 15, 620-626. [CrossRef]

126. Steinfelder, S.; Andersen, J.F.; Cannons, J.L.; Feng, C.G.; Joshi, M.; Dwyer, D.; Caspar, P.; Schwartzberg, P.L.; Sher, A.; Jankovic, D. The major component in schistosome eggs responsible for conditioning dendritic cells for Th2 polarization is a T2 ribonuclease (omega-1). J. Exp. Med. 2009, 206, 1681-1690. [CrossRef]

127. Everts, B.; Hussaarts, L.; Driessen, N.N.; Meevissen, M.H.; Schramm, G.; van der Ham, A.J.; van der Hoeven, B.; Scholzen, T.; Burgdorf, S.; Mohrs, M.; et al. Schistosome-derived omega-1 drives Th2 polarization by suppressing protein synthesis following internalization by the mannose receptor. J. Exp. Med. 2012, 209, 1753-1767. [CrossRef]

128. Eisenbarth, S.C.; Piggott, D.A.; Huleatt, J.W.; Visintin, I.; Herrick, C.A.; Bottomly, K. Lipopolysaccharide-enhanced, toll-like receptor 4-dependent $\mathrm{T}$ helper cell type 2 responses to inhaled antigen. J. Exp. Med. 2002, 196, 1645-1651. [CrossRef]

129. Dillon, S.; Agrawal, A.; Van Dyke, T.; Landreth, G.; McCauley, L.; Koh, A.; Maliszewski, C.; Akira, S.; Pulendran, B. A Toll-like receptor 2 ligand stimulates Th2 responses in vivo, via induction of extracellular signal-regulated kinase mitogen-activated protein kinase and c-Fos in dendritic cells. J. Immunol. 2004, 172, 4733-4743. [CrossRef]

130. Goodridge, H.S.; Marshall, F.A.; Else, K.J.; Houston, K.M.; Egan, C.; Al-Riyami, L.; Liew, F.Y.; Harnett, W.; Harnett, M.M. Immunomodulation via novel use of TLR4 by the filarial nematode phosphorylcholine-containing secreted product, ES-62. J. Immunol. 2005, 174, 284-293. [CrossRef]

131. Goodridge, H.S.; McGuiness, S.; Houston, K.M.; Egan, C.A.; Al-Riyami, L.; Alcocer, M.J.; Harnett, M.M.; Harnett, W. Phosphorylcholine mimics the effects of ES-62 on macrophages and dendritic cells. Parasite Immunol. 2007, 29, 127-137. [CrossRef]

132. Thomas, P.G.; Carter, M.R.; Atochina, O.; Da'Dara, A.A.; Piskorska, D.; McGuire, E.; Harn, D.A. Maturation of dendritic cell 2 phenotype by a helminth glycan uses a Toll-like receptor 4-dependent mechanism. J. Immunol. 2003, 171, 5837-5841. [CrossRef] [PubMed]

133. Arruda, L.K.; Santos, A.B. Immunologic responses to common antigens in helminthic infections and allergic disease. Curr. Opin. Allergy Clin. Immunol. 2005, 5, 399-402. [CrossRef] [PubMed]

134. Kamal, S.M.; El Sayed Khalifa, K. Immune modulation by helminthic infections: Worms and viral infections. Parasite Immunol. 2006, 28, 483-496. [CrossRef] [PubMed]

135. Shinoda, K.; Hirahara, K.; Nakayama, T. Maintenance of pathogenic Th2 cells in allergic disorders. Allergol. Int. Off. J. Jpn. Soc. Allergol. 2017, 66, 369-376. [CrossRef] [PubMed]

136. Zhong, H.; Fan, X.L.; Yu, Q.N.; Qin, Z.L.; Chen, D.; Xu, R.; Chen, D.H.; Lin, Z.B.; Wen, W.; Fu, Q.L. Increased innate type 2 immune response in house dust mite-allergic patients with allergic rhinitis. Clin. Immunol. 2017, 183, 293-299. [CrossRef]

137. Ege, M.; Ma, Y.; Manfras, B.; Kalwak, K.; Lu, H.; Lieber, M.R.; Schwarz, K.; Pannicke, U. Omenn syndrome due to ARTEMIS mutations. Blood 2005, 105, 4179-4186. [CrossRef] [PubMed] 
138. Vroman, H.; Bergen, I.M.; van Hulst, J.A.C.; van Nimwegen, M.; van Uden, D.; Schuijs, M.J.; Pillai, S.Y.; van Loo, G.; Hammad, H.; Lambrecht, B.N.; et al. TNF-alpha-induced protein 3 levels in lung dendritic cells instruct TH2 or TH17 cell differentiation in eosinophilic or neutrophilic asthma. J. Allergy Clin. Immunol. 2018, 141, 1620-1633. [CrossRef]

139. Froidure, A.; Shen, C.; Gras, D.; Van Snick, J.; Chanez, P.; Pilette, C. Myeloid dendritic cells are primed in allergic asthma for thymic stromal lymphopoietin-mediated induction of Th2 and Th9 responses. Allergy 2014, 69, 1068-1076. [CrossRef]

140. Sanyal, R.D.; Pavel, A.B.; Glickman, J.; Chan, T.C.; Zheng, X.; Zhang, N.; Cueto, I.; Peng, X.; Estrada, Y.; Fuentes-Duculan, J.; et al. Atopic dermatitis in African American patients is TH2/TH22-skewed with TH1/TH17 attenuation. Ann. Allergy Asthma Immunol. Off. Publ. Am. Coll. Allergy Asthma Immunol. 2019, 122, 99-110. [CrossRef]

141. Suarez-Farinas, M.; Dhingra, N.; Gittler, J.; Shemer, A.; Cardinale, I.; de Guzman Strong, C.; Krueger, J.G.; Guttman-Yassky, E. Intrinsic atopic dermatitis shows similar TH2 and higher TH17 immune activation compared with extrinsic atopic dermatitis. J. Allergy Clin. Immunol. 2013, 132, 361-370. [CrossRef]

142. Brandt, E.B.; Sivaprasad, U. Th2 Cytokines and Atopic Dermatitis. J. Clin. Cell. Immunol. $2011,2,3$. [CrossRef] [PubMed]

143. Scaletti, C.; Vultaggio, A.; Bonifacio, S.; Emmi, L.; Torricelli, F.; Maggi, E.; Romagnani, S.; Piccinni, M.P. Th2-oriented profile of male offspring $\mathrm{T}$ cells present in women with systemic sclerosis and reactive with maternal major histocompatibility complex antigens. Arthritis Rheum. 2002, 46, 445-450. [CrossRef]

144. Wallace, W.A.; Ramage, E.A.; Lamb, D.; Howie, S.E. A type 2 (Th2-like) pattern of immune response predominates in the pulmonary interstitium of patients with cryptogenic fibrosing alveolitis (CFA). Clin. Exp. Immunol. 1995, 101, 436-441. [CrossRef] [PubMed]

145. Souto, G.R.; Queiroz-Junior, C.M.; de Abreu, M.H.; Costa, F.O.; Mesquita, R.A. Pro-inflammatory, Th1, Th2, Th17 cytokines and dendritic cells: A cross-sectional study in chronic periodontitis. PLoS ONE 2014, 9, e91636. [CrossRef] [PubMed]

146. Vasilescu, A.; Heath, S.C.; Ivanova, R.; Hendel, H.; Do, H.; Mazoyer, A.; Khadivpour, E.; Goutalier, F.X.; Khalili, K.; Rappaport, J.; et al. Genomic analysis of Th1-Th2 cytokine genes in an AIDS cohort: identification of IL4 and IL10 haplotypes associated with the disease progression. Genes Immunity 2003, 4, 441-449. [CrossRef]

147. Block, M.S.; Nevala, W.K.; Leontovich, A.A.; Markovic, S.N. Differential response of human and mouse dendritic cells to VEGF determines interspecies discrepancies in tumor-mediated TH1/TH2 polarity shift. Clin. Cancer Res. Off. J. Am. Assoc. Cancer Res. 2011, 17, 1776-1783. [CrossRef] [PubMed]

148. Gause, W.C.; Wynn, T.A.; Allen, J.E. Type 2 immunity and wound healing: Evolutionary refinement of adaptive immunity by helminths. Nat. Rev. Immunol. 2013, 13, 607-614. [CrossRef]

149. Phythian-Adams, A.T.; Cook, P.C.; Lundie, R.J.; Jones, L.H.; Smith, K.A.; Barr, T.A.; Hochweller, K.; Anderton, S.M.; Hammerling, G.J.; Maizels, R.M.; et al. CD11c depletion severely disrupts Th2 induction and development in vivo. J. Exp. Med. 2010, 207, 2089-2096. [CrossRef]

150. Smith, K.A.; Harcus, Y.; Garbi, N.; Hammerling, G.J.; MacDonald, A.S.; Maizels, R.M. Type 2 innate immunity in helminth infection is induced redundantly and acts autonomously following $\mathrm{CD} 11 \mathrm{c}(+)$ cell depletion. Infect. Immunity 2012, 80, 3481-3489. [CrossRef]

151. Smith, K.A.; Hochweller, K.; Hammerling, G.J.; Boon, L.; MacDonald, A.S.; Maizels, R.M. Chronic helminth infection promotes immune regulation in vivo through dominance of CD11cloCD103- dendritic cells. J. Immunol. 2011, 186, 7098-7109. [CrossRef] [PubMed]

152. Massacand, J.C.; Stettler, R.C.; Meier, R.; Humphreys, N.E.; Grencis, R.K.; Marsland, B.J.; Harris, N.L. Helminth products bypass the need for TSLP in Th2 immune responses by directly modulating dendritic cell function. Proc. Natl. Acad. Sci. USA 2009, 106, 13968-13973. [CrossRef]

153. Taylor, B.C.; Zaph, C.; Troy, A.E.; Du, Y.; Guild, K.J.; Comeau, M.R.; Artis, D. TSLP regulates intestinal immunity and inflammation in mouse models of helminth infection and colitis. J. Exp. Med. 2009, 206, 655-667. [CrossRef] [PubMed]

154. Medzhitov, R.; Janeway, C.A., Jr. Innate immunity: The virtues of a nonclonal system of recognition. Cell 1997, 91, 295-298. [CrossRef]

155. Akira, S.; Takeda, K.; Kaisho, T. Toll-like receptors: Critical proteins linking innate and acquired immunity. Nat. Immunol. 2001, 2, 675-680. [CrossRef] [PubMed] 
156. Kaisho, T.; Hoshino, K.; Iwabe, T.; Takeuchi, O.; Yasui, T.; Akira, S. Endotoxin can induce MyD88-deficient dendritic cells to support $\mathrm{T}(\mathrm{h}) 2$ cell differentiation. Int. Immunol. 2002, 14, 695-700. [CrossRef]

157. Plantinga, M.; Guilliams, M.; Vanheerswynghels, M.; Deswarte, K.; Branco-Madeira, F.; Toussaint, W.; Vanhoutte, L.; Neyt, K.; Killeen, N.; Malissen, B.; et al. Conventional and monocyte-derived CD11b(+) dendritic cells initiate and maintain T helper 2 cell-mediated immunity to house dust mite allergen. Immunity 2013, 38, 322-335. [CrossRef] [PubMed]

158. Furuhashi, K.; Suda, T.; Hasegawa, H.; Suzuki, Y.; Hashimoto, D.; Enomoto, N.; Fujisawa, T.; Nakamura, Y.; Inui, N.; Shibata, K.; et al. Mouse lung CD103+ and CD11bhigh dendritic cells preferentially induce distinct CD4+ T-cell responses. Am. J. Respir. Cell Mol. Biol. 2012, 46, 165-172. [CrossRef] [PubMed]

159. Raymond, M.; Rubio, M.; Fortin, G.; Shalaby, K.H.; Hammad, H.; Lambrecht, B.N.; Sarfati, M. Selective control of SIRP-alpha-positive airway dendritic cell trafficking through CD47 is critical for the development of T(H)2-mediated allergic inflammation. J. Allergy Clin. Immunol. 2009, 124, 1333-1342. [CrossRef]

160. Norimoto, A.; Hirose, K.; Iwata, A.; Tamachi, T.; Yokota, M.; Takahashi, K.; Saijo, S.; Iwakura, Y.; Nakajima, H. Dectin-2 promotes house dust mite-induced T helper type 2 and type 17 cell differentiation and allergic airway inflammation in mice. Am. J. Respir. Cell Mol. Biol. 2014, 51, 201-209.

161. Deckers, J.; Sichien, D.; Plantinga, M.; Van Moorleghem, J.; Vanheerswynghels, M.; Hoste, E.; Malissen, B.; Dombrowicz, D.; Guilliams, M.; De Bosscher, K.; et al. Epicutaneous sensitization to house dust mite allergen requires interferon regulatory factor 4-dependent dermal dendritic cells. J. Allergy Clin. Immunol. 2017, 140, 1364-1377. [CrossRef] [PubMed]

162. Han, J.; Dakhama, A.; Jia, Y.; Wang, M.; Zeng, W.; Takeda, K.; Shiraishi, Y.; Okamoto, M.; Ziegler, S.F.; Gelfand, E.W. Responsiveness to respiratory syncytial virus in neonates is mediated through thymic stromal lymphopoietin and OX40 ligand. J. Allergy Clin. Immunol. 2012, 130, 1175-1189. [CrossRef]

163. De Kleer, I.M.; Kool, M.; de Bruijn, M.J.; Willart, M.; van Moorleghem, J.; Schuijs, M.J.; Plantinga, M.; Beyaert, R.; Hams, E.; Fallon, P.G.; et al. Perinatal Activation of the Interleukin-33 Pathway Promotes Type 2 Immunity in the Developing Lung. Immunity 2016, 45, 1285-1298. [CrossRef] [PubMed]

164. Williams, H.C. Clinical practice. Atopic dermatitis. N. Engl. J. Med. 2005, 352, 2314-2324. [CrossRef]

165. Bieber, T.; de la Salle, H.; Wollenberg, A.; Hakimi, J.; Chizzonite, R.; Ring, J.; Hanau, D.; de la Salle, C. Human epidermal Langerhans cells express the high affinity receptor for immunoglobulin E (Fc epsilon RI). J. Exp. Med. 1992, 175, 1285-1290. [CrossRef]

166. Wang, B.; Rieger, A.; Kilgus, O.; Ochiai, K.; Maurer, D.; Fodinger, D.; Kinet, J.P.; Stingl, G. Epidermal Langerhans cells from normal human skin bind monomeric IgE via Fc epsilon RI. J. Exp. Med. 1992, 175, 1353-1365. [CrossRef] [PubMed]

167. Novak, N.; Bieber, T. The role of dendritic cell subtypes in the pathophysiology of atopic dermatitis. J. Am. Acad. Derm. 2005, 53, S171-S176. [CrossRef]

168. Bieber, T. The pro- and anti-inflammatory properties of human antigen-presenting cells expressing the high affinity receptor for IgE (Fc epsilon RI). Immunobiology 2007, 212, 499-503. [CrossRef] [PubMed]

169. Novak, N.; Valenta, R.; Bohle, B.; Laffer, S.; Haberstok, J.; Kraft, S.; Bieber, T. FcepsilonRI engagement of Langerhans cell-like dendritic cells and inflammatory dendritic epidermal cell-like dendritic cells induces chemotactic signals and different T-cell phenotypes in vitro. J. Allergy Clin. Immunol. 2004, 113, 949-957. [CrossRef] [PubMed]

170. Kerschenlohr, K.; Decard, S.; Przybilla, B.; Wollenberg, A. Atopy patch test reactions show a rapid influx of inflammatory dendritic epidermal cells in patients with extrinsic atopic dermatitis and patients with intrinsic atopic dermatitis. J. Allergy Clin. Immunol. 2003, 111, 869-874. [CrossRef] [PubMed]

171. Takano, K.; Kojima, T.; Go, M.; Murata, M.; Ichimiya, S.; Himi, T.; Sawada, N. HLA-DR- and CD11c-positive dendritic cells penetrate beyond well-developed epithelial tight junctions in human nasal mucosa of allergic rhinitis. J. Histochem. Cytochem. 2005, 53, 611-619. [CrossRef]

172. Shen, C.; Hupin, C.; Froidure, A.; Detry, B.; Pilette, C. Impaired ICOSL in human myeloid dendritic cells promotes Th2 responses in patients with allergic rhinitis and asthma. Clin. Exp. Allergy J. Br. Soc. Allergy Clin. Immunol. 2014, 44, 831-841. [CrossRef]

173. Kaur, D.; Brightling, C. OX40/OX40 ligand interactions in T-cell regulation and asthma. Chest 2012, 141, 494-499. [CrossRef] 
174. Gauvreau, G.M.; Boulet, L.P.; Cockcroft, D.W.; FitzGerald, J.M.; Mayers, I.; Carlsten, C.; Laviolette, M.; Killian, K.J.; Davis, B.E.; Larche, M.; et al. OX40L blockade and allergen-induced airway responses in subjects with mild asthma. Clin. Exp. Allergy 2014, 44, 29-37. [CrossRef]

175. Gauvreau, G.M.; O’Byrne, P.M.; Boulet, L.P.; Wang, Y.; Cockcroft, D.; Bigler, J.; FitzGerald, J.M.; Boedigheimer, M.; Davis, B.E.; Dias, C.; et al. Effects of an anti-TSLP antibody on allergen-induced asthmatic responses. N. Engl. J. Med. 2014, 370, 2102-2110. [CrossRef]

176. Romagnani, S. T-cell subsets (Th1 versus Th2). Ann. Allergy Asthma Immunol. 2000, 85, 9-18. [CrossRef]

177. Jaffary, F.; Faghihi, G.; Mokhtarian, A.; Hosseini, S.M. Effects of oral vitamin E on treatment of atopic dermatitis: A randomized controlled trial. J. Res. Med. Sci. 2015, 20, 1053-1057.

178. Li-Weber, M.; Salgame, P.; Hu, C.; Davydov, I.V.; Laur, O.; Klevenz, S.; Krammer, P.H. Th2-specific protein/DNA interactions at the proximal nuclear factor-AT site contribute to the functional activity of the human IL-4 promoter. J. Immunol. 1998, 161, 1380-1389.

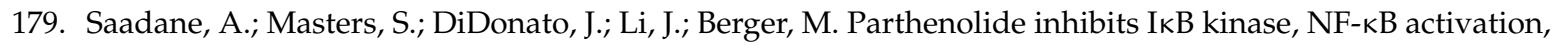
and inflammatory response in cystic fibrosis cells and mice. Am. J. Respir. Cell Mol. Biol. 2007, 36, 728-736. [CrossRef]

180. Nanda, A.; Wasan, A. Allergic contact dermatitis to parthenolide. J. Allergy Clin. Immunol. Pr. 2016, 4, 993-994. [CrossRef]

181. Perez, G.M.; Melo, M.; Keegan, A.D.; Zamorano, J. Aspirin and salicylates inhibit the IL-4- and IL-13-induced activation of STAT6. J. Immunol. 2002, 168, 1428-1434. [CrossRef]

182. Wu, K.C.P.; Jabbar-Lopez, Z.K. Omalizumab, an Anti-IgE mAb, receives approval for the treatment of chronic idiopathic/spontaneous urticaria. J. Investig. Derm. 2015, 135, 13-15. [CrossRef]

183. Vashisht, P.; Casale, T. Omalizumab for treatment of allergic rhinitis. Expert. Opin. Biol. 2013, 13, 933-945. [CrossRef]

184. Loizou, D.; Enav, B.; Komlodi-Pasztor, E.; Hider, P.; Kim-Chang, J.; Noonan, L.; Taber, T.; Kaushal, S.; Limgala, R.; Brown, M.; et al. A pilot study of omalizumab in eosinophilic esophagitis. PLoS ONE 2015, 10, e0113483. [CrossRef]

185. Lieberman, J.A.; Chehade, M. Use of omalizumab in the treatment of food allergy and anaphylaxis. Curr. Allergy Asthma Rep. 2013, 13, 78-84. [CrossRef]

186. Wang, H.H.; Li, Y.C.; Huang, Y.C. Efficacy of omalizumab in patients with atopic dermatitis: A systematic review and meta-analysis. J. Allergy Clin. Immunol. 2016, 138, 1719-1722. [CrossRef]

187. Tsianakas, A.; Luger, T.A.; Radin, A. Dupilumab treatment improves quality of life in adult patients with moderate-to-severe atopic dermatitis: Results from a randomized, placebo-controlled clinical trial. Br. J. Derm. 2018, 178, 406-414. [CrossRef]

188. Simpson, E.L.; Bieber, T.; Guttman-Yassky, E.; Beck, L.A.; Blauvelt, A.; Cork, M.J.; Silverberg, J.I.; Deleuran, M.; Kataoka, Y.; Lacour, J.P.; et al. Two Phase 3 Trials of Dupilumab versus Placebo in Atopic Dermatitis. N. Engl. J. Med. 2016, 375, 2335-2348. [CrossRef]

189. Thomson, N.C.; Patel, M.; Smith, A.D. Lebrikizumab in the personalized management of asthma. Biologics 2012, 6, 329-335. [CrossRef]

190. Corren, J.; Lemanske, R.F.; Hanania, N.A.; Korenblat, P.E.; Parsey, M.V.; Arron, J.R.; Harris, J.M.; Scheerens, H.; Wu, L.C.; Su, Z.; et al. Lebrikizumab treatment in adults with asthma. N. Engl. J. Med. 2011, 365, 1088-1098. [CrossRef]

191. Noonan, M.; Korenblat, P.; Mosesova, S.; Scheerens, H.; Arron, J.R.; Zheng, Y.; Putnam, W.S.; Parsey, M.V.; Bohen, S.P.; Matthews, J.G. Dose-ranging study of lebrikizumab in asthmatic patients not receiving inhaled steroids. J. Allergy Clin. Immunol. 2013, 132, 567-574. [CrossRef]

192. Piper, E.; Brightling, C.; Niven, R.; Oh, C.; Faggioni, R.; Poon, K.; She, D.; Kell, C.; May, R.D.; Geba, G.P.; et al. A phase II placebo-controlled study of tralokinumab in moderate-to-severe asthma. Eur. Respir. J. 2013, 41, 330-338. [CrossRef]

193. De Boever, E.H.; Ashman, C.; Cahn, A.P.; Locantore, N.W.; Overend, P.; Pouliquen, I.J.; Serone, A.P.; Wright, T.J.; Jenkins, M.M.; Panesar, I.S.; et al. Efficacy and safety of an anti-IL-13 mAb in patients with severe asthma: A randomized trial. J. Allergy Clin. Immunol. 2014, 133, 989-996. [CrossRef]

194. Hart, T.K.; Blackburn, M.N.; Brigham-Burke, M.; Dede, K.; Al-Mahdi, N.; Zia-Amirhosseini, P.; Cook, R.M. Preclinical efficacy and safety of pascolizumab (SB 240683): A humanized anti-interleukin-4 antibody with therapeutic potential in asthma. Clin. Exp. Immunol. 2002, 130, 93-100. [CrossRef] 
195. Antoniu, S.A. Pitrakinra, a dual IL-4/IL-13 antagonist for the potential treatment of asthma and eczema. Curr. Opin. Investig. Drugs 2010, 11, 1286-1294.

196. Pavord, I.D.; Korn, S.; Howarth, P.; Bleecker, E.R.; Buhl, R.; Keene, O.N.; Ortega, H.; Chanez, P. Mepolizumab for severe eosinophilic asthma (DREAM): A multicentre, double-blind, placebo-controlled trial. Lancet 2012, 380, 651-659. [CrossRef]

197. Ortega, H.G.; Liu, M.C.; Pavord, I.D.; Brusselle, G.G.; FitzGerald, J.M.; Chetta, A.; Humbert, M.; Katz, L.E.; Keene, O.N.; Yancey, S.W.; et al. Mepolizumab treatment in patients with severe eosinophilic asthma. N. Engl. J. Med. 2014, 371, 1198-1207. [CrossRef]

198. Reynolds, G.; Haniffa, M. Human and Mouse Mononuclear Phagocyte Networks: A Tale of Two Species? Front. Immunol. 2015, 6, 330. [CrossRef]

199. Bel, E.H.; Wenzel, S.E.; Thompson, P.J.; Prazma, C.M.; Keene, O.N.; Yancey, S.W.; Ortega, H.G.; Pavord, I.D.; Investigators, S. Oral glucocorticoid-sparing effect of mepolizumab in eosinophilic asthma. N. Engl. J. Med. 2014, 371, 1189-1197. [CrossRef]

200. Hom, S.; Pisano, M. Reslizumab (Cinqair): An Interleukin-5 Antagonist for Severe Asthma of the Eosinophilic Phenotype. Pharm. Ther. 2017, 42, 564-568.

201. FitzGerald, J.M.; Bleecker, E.R.; Nair, P.; Korn, S.; Ohta, K.; Lommatzsch, M.; Ferguson, G.T.; Busse, W.W.; Barker, P.; Sproule, S.; et al. Benralizumab, an anti-interleukin-5 receptor alpha monoclonal antibody, as add-on treatment for patients with severe, uncontrolled, eosinophilic asthma (CALIMA): A randomised, double-blind, placebo-controlled phase 3 trial. Lancet 2016, 388, 2128-2141. [CrossRef]

202. Hua, F.; Ribbing, J.; Reinisch, W.; Cataldi, F.; Martin, S. A pharmacokinetic comparison of anrukinzumab, an anti- IL-13 monoclonal antibody, among healthy volunteers, asthma and ulcerative colitis patients. Br. J. Clin. Pharm. 2015, 80, 101-109. [CrossRef] [PubMed]

203. Gauvreau, G.M.; Arm, J.P.; Boulet, L.P.; Leigh, R.; Cockcroft, D.W.; Davis, B.E.; Mayers, I.; FitzGerald, J.M.; Dahlen, B.; Killian, K.J.; et al. Efficacy and safety of multiple doses of QGE031 (ligelizumab) versus omalizumab and placebo in inhibiting allergen-induced early asthmatic responses. J. Allergy Clin. Immunol. 2016, 138, 1051-1059. [CrossRef] [PubMed]

204. Ruzicka, T.; Hanifin, J.M.; Furue, M.; Pulka, G.; Mlynarczyk, I.; Wollenberg, A.; Galus, R.; Etoh, T.; Mihara, R.; Yoshida, H.; et al. Anti-Interleukin-31 Receptor A Antibody for Atopic Dermatitis. N. Engl. J. Med. 2017, 376, 826-835. [CrossRef] [PubMed]

205. Leonardi, C.L.; Kimball, A.B.; Papp, K.A.; Yeilding, N.; Guzzo, C.; Wang, Y.; Li, S.; Dooley, L.T.; Gordon, K.B.; PHOENIX 1 Study Investigators. Efficacy and safety of ustekinumab, a human interleukin-12/23 monoclonal antibody, in patients with psoriasis: 76-week results from a randomised, double-blind, placebo-controlled trial (PHOENIX 1). Lancet 2008, 371, 1665-1674.

206. Wlodek, C.; Hewitt, H.; Kennedy, C.T. Use of ustekinumab for severe refractory atopic dermatitis in a young teenager. Clin. Exp. Derm. 2016, 41, 625-627. [CrossRef] [PubMed]

207. Montes-Torres, A.; Llamas-Velasco, M.; Perez-Plaza, A.; Solano-Lopez, G.; Sanchez-Perez, J. Biological Treatments in Atopic Dermatitis. J. Clin. Med. 2015, 4, 593-613. [CrossRef]

208. Okoye, I.S.; Czieso, S.; Ktistaki, E.; Roderick, K.; Coomes, S.M.; Pelly, V.S.; Kannan, Y.; Perez-Lloret, J.; Zhao, J.L.; Baltimore, D.; et al. Transcriptomics identified a critical role for Th2 cell-intrinsic miR-155 in mediating allergy and antihelminth immunity. Proc. Natl. Acad. Sci. USA 2014, 111, E3081-E3090. [CrossRef]

209. Malmhall, C.; Alawieh, S.; Lu, Y.; Sjostrand, M.; Bossios, A.; Eldh, M.; Radinger, M. MicroRNA-155 is essential for $\mathrm{T}(\mathrm{H}) 2$-mediated allergen-induced eosinophilic inflammation in the lung. J. Allergy Clin. Immunol. 2014, 133, 1429-1438. [CrossRef]

210. Mattes, J.; Collison, A.; Plank, M.; Phipps, S.; Foster, P.S. Antagonism of microRNA-126 suppresses the effector function of TH2 cells and the development of allergic airways disease. Proc. Natl. Acad. Sci. USA 2009, 106, 18704-18709. [CrossRef]

211. Xiao, L.; Jiang, L.; Hu, Q.; Li, Y. MicroRNA-133b Ameliorates Allergic Inflammation and Symptom in Murine Model of Allergic Rhinitis by Targeting Nlrp3. Cell Physiol. Biochem. 2017, 42, 901-912. [CrossRef]

212. Luo, Y.; Deng, Y.; Tao, Z.; Chen, S.; Xiao, B.; Ren, J.; Chen, Z.; Han, J.; Kong, Y.; Xu, Y.; et al. Regulatory effect of microRNA-135a on the Th1/Th2 imbalance in a murine model of allergic rhinitis. Exp. Med. 2014, 8, 1105-1110. [CrossRef] 
213. Tang, H.; Jiang, H.; Zheng, J.; Li, J.; Wei, Y.; Xu, G.; Li, H. MicroRNA-106b regulates pro-allergic properties of dendritic cells and Th2 polarisation by targeting early growth response-2 in vitro. Int. Immunopharmacol. 2015, 28, 866-874. [CrossRef] [PubMed]

214. Qiu, Y.Y.; Zhang, Y.W.; Qian, X.F.; Bian, T. miR-371, miR-138, miR-544, miR-145, and miR-214 could modulate Th1/Th2 balance in asthma through the combinatorial regulation of Runx3. Am. J. Transl. Res. 2017, 9, 3184-3199.

215. Cury Martins, J.; Martins, C.; Aoki, V.; Gois, A.F.; Ishii, H.A.; da Silva, E.M. Topical tacrolimus for atopic dermatitis. Cochrane Database Syst. Rev. 2015, 7, CD009864. [CrossRef]

216. Ho, S.; Clipstone, N.; Timmermann, L.; Northrop, J.; Graef, I.; Fiorentino, D.; Nourse, J.; Crabtree, G.R. The mechanism of action of cyclosporin A and FK506. Clin. Immunol. Immunopathol. 1996, 80, S40-S45. [CrossRef] [PubMed]

217. Morita, Y.; Yang, J.; Gupta, R.; Shimizu, K.; Shelden, E.A.; Endres, J.; Mule, J.J.; McDonagh, K.T.; Fox, D.A. Dendritic cells genetically engineered to express IL-4 inhibit murine collagen-induced arthritis. J. Clin. Investig. 2001, 107, 1275-1284. [CrossRef] [PubMed]

218. Takemura, M.; Nakahara, T.; Hashimoto-Hachiya, A.; Furue, M.; Tsuji, G. Glyteer, Soybean Tar, Impairs IL-4/Stat6 Signaling in Murine Bone Marrow-Derived Dendritic Cells: The Basis of Its Therapeutic Effect on Atopic Dermatitis. Int. J. Mol. Sci. 2018, 19, 1169. [CrossRef]

219. Lee, J.; Park, C.O.; Lee, K.H. Specific immunotherapy in atopic dermatitis. Allergy Asthma Immunol. Res. 2015, 7, 221-229. [CrossRef]

220. Gross, C.C.; Wiendl, H. Dendritic cell vaccination in autoimmune disease. Curr. Opin. Rheumatol. 2013, 25, 268-274. [CrossRef]

221. Novak, N. An update on the role of human dendritic cells in patients with atopic dermatitis. J. Allergy Clin. Immunol. 2012, 129, 879-886. [CrossRef]

222. Gutowska-Owsiak, D.; Ogg, G.S. Therapeutic vaccines for allergic disease. NPJ Vaccines 2017, 2, 12. [CrossRef]

223. Burke, J.M.; Ganley-Leal, L.M.; Khatri, A.; Wetzler, L.M. Neisseria meningitidis PorB, a TLR2 ligand, induces an antigen-specific eosinophil recall response: Potential adjuvant for helminth vaccines? J. Immunol. 2007, 179, 3222-3230. [CrossRef] [PubMed]

224. Benito-Villalvilla, C.; Soria, I.; Subiza, J.L.; Palomares, O. Novel vaccines targeting dendritic cells by coupling allergoids to mannan. Allergo J. Int. 2018, 27, 256-262. [CrossRef] [PubMed]

225. Chen, P.; Liu, X.; Sun, Y.; Zhou, P.; Wang, Y.; Zhang, Y. Dendritic cell targeted vaccines: Recent progresses and challenges. Hum. Vaccin Immunother. 2016, 12, 612-622. [CrossRef] [PubMed]

226. Bach, J.F. The hygiene hypothesis in autoimmunity: The role of pathogens and commensals. Nat. Rev. Immunol. 2018, 18, 105-120. [CrossRef]

227. Lambrecht, B.N.; Hammad, H. The immunology of the allergy epidemic and the hygiene hypothesis. Nat. Immunol. 2017, 18, 1076-1083. [CrossRef] [PubMed]

228. Liu, A.H. Revisiting the hygiene hypothesis for allergy and asthma. J. Allergy Clin. Immunol. 2015, 136, 860-865. [CrossRef]

229. Okada, H.; Kuhn, C.; Feillet, H.; Bach, J.F. The "hygiene hypothesis" for autoimmune and allergic diseases: An update. Clin. Exp. Immunol. 2010, 160,1-9. [CrossRef] [PubMed]

230. Maizels, R.M. Parasitic helminth infections and the control of human allergic and autoimmune disorders. Clin. Microbiol. Infect. 2016, 22, 481-486. [CrossRef] [PubMed]

(C) 2019 by the authors. Licensee MDPI, Basel, Switzerland. This article is an open access article distributed under the terms and conditions of the Creative Commons Attribution (CC BY) license (http://creativecommons.org/licenses/by/4.0/). 